Article

\title{
Relationship between International Reserves and FX Rate Movements
}

\author{
Yeonjeong Lee ${ }^{1, *}$ and Seong-Min Yoon ${ }^{2, *(D)}$ \\ 1 Institute of Economics and International Trade, Pusan National University, Busan 46241, Korea \\ 2 Department of Economics, Pusan National University, Busan 46241, Korea \\ * Correspondence: yeonjeong@pusan.ac.kr (Y.L.); smyoon@pusan.ac.kr (S.-M.Y.); \\ Tel.: +82-51-510-3378 (Y.L.); +82-51-510-2557 (S.-M.Y.)
}

Received: 29 July 2020; Accepted: 13 August 2020; Published: 26 August 2020

\begin{abstract}
This paper investigates the relationship between international reserves changes and foreign exchange rate movements for five Far Eastern countries (China, Japan, Taiwan, Hong Kong, and Korea) from January 1997 to May 2020. We use the quantile Granger causality test and the quantile autoregressive model to capture the monetary authorities' motivations for intervention. The primary results of this study are as follows. First, in China and Hong Kong, we capture the mercantilists' motive of accumulating their international reserves for the purpose of responding to the appreciation of currencies. Relatively speaking, the monetary authorities' motivation for precautionary stabilizing their currencies is high in Korea and Japan. Second, we identify the asymmetric causal relationship between the variables. Considering the causal relationship with significant regression coefficients, these characteristics are found to be more evident in all countries. Last, we confirm the properties of the quantile- and tail-dependent relationship between the variables. In particular, Korea has a relatively stronger tail-dependence than other countries. That is, the causal relationship between the Korean foreign exchange reserves and the exchange rate is stronger at the rapid fluctuations of the variables, and this relationship is weakened at the moderate fluctuations of them.
\end{abstract}

Keywords: exchange rate; international reserves; intervention; quantile analysis

\section{Introduction}

The collapse of the Bretton Woods fixed exchange rate system in the early 1970s initiated the flexible exchange rate system. Most countries have chosen a pure flexible exchange rate system, in which monetary authorities do not intervene at all in their foreign exchange market. The pure flexible exchange rate system means that the exchange rate is determined autonomously by market forces such that the inflow and outflow of foreign exchange is balanced.

Interestingly, however, the rate at which a country accumulates foreign exchange reserves to defend fixed exchange rates has not changed even after the adoption of a flexible exchange rate system. This can be seen as a sign of scepticism about the flexible exchange rate system. The flexible exchange rate system faced problems of high exchange rate volatility and weakening competitiveness in the major developed countries. The excessive overvaluation of the U.S. dollar in the early- and mid-1980s, and then the devaluation of the dollar in the late 1980s led the G7 developed countries to agree to a coordinated formal intervention to stabilize the value of the U.S. dollar within an informal baseline [1,2]. Since then, policymakers have been tasked with adjusting the advantages of flexibility of exchange rate as a shock absorber on one hand and as a mechanism to facilitate international competitiveness and macroeconomic stability on the other.

In recent years, huge swings in global capital flows have led many countries, including emerging market economies, to reconsider their foreign exchange market intervention strategies [3-5]. 
Monetary authorities engage in the sale of foreign exchange to reduce the volatility of exchange rates affecting international trade, international financial flows, and foreign investment, or, with the ultimate goal of strengthening the nation's macroeconomic fundamentals, to influence the value of its currency $[6,7]$.

Foreign exchange reserves are widely used as an official means of intervention in foreign exchange markets. Monetary authorities around the world have adjusted the level or volatility of their currency prices by buying and selling foreign exchange to prevent, as argued by Calvo and Reinhart [8], the outbreak of the "fear of floating." This practice means that the exchange rate system of countries around the world is in fact a managed flexible exchange rate system.

Theoretically, under a pure flexible exchange rate system, countries need not have reserve requirements. Even though under a pure flexible exchange rate system, countries may still hold reserves as a precaution in the event that they return to a fixed exchange rate system. Thus, regardless of the exchange rate between countries, the demand for reserves always exists [9]. However, since the 1990s, global foreign exchange reserves have increased gradually, especially in emerging economies. Between 1999 and 2008, China's foreign exchange reserves tripled and increased to $\$ 300$ billion, but they increased more than tenfold over the next decade. As of April 2020, China had accumulated $\$ 3.1$ trillion in foreign reserves, while the Asian countries' foreign reserves had also increased sharply, including Japan's \$1.4 trillion, Hong Kong's \$441.3 billion, Taiwan's $\$ 481.8$ billion, and Korea's $\$ 404.0$ billion [10]. In the midst of the increasing global financial imbalance, the surge in foreign exchange reserves in emerging economies has attracted the attention of academics, policymakers, and financial market investors and has generated several controversies [11]. As Bernanke [12] argued, an unprecedented amount of foreign exchange reserves contributed to excess savings that led to global imbalances, and it is closely related to the recent global financial crisis [12-17]. On the contrary, Borio and Disyatat [18] argued that the global imbalances cannot be the cause of the financial crisis, and that it is more important to address the weaknesses of the international monetary and financial system directly.

Emerging economies are a good case to analyze the relationship between changes in foreign exchange reserves and fluctuations in exchange rates. Foreign exchange intervention is more effective in developing countries than in advanced industrialized countries. One reason for this is that in the developing countries, the intervention in the foreign exchange market is not fully sterilized. In other words, monetary authorities in the countries fail to take sufficient actions to offset the impact of fluctuations in foreign asset holdings on the domestic currency base [2]. Other reason is that the scale of intervention is too large compared to the narrow foreign exchange market. In addition, the central bank also has the advantage of having more information than other market participants [19]. This is also because financial markets are incomplete in emerging economies, resulting in the costly and sometimes impossible hedging of exchange rate risks [20] and in significant exchange rate volatility for individual economic players and economies [6]. Even if successful intervention is made, the nominal exchange rates of emerging economies cannot avoid some volatility [19]. Moreover, due to the external liabilities denominated in foreign currencies, emerging markets have many foreign exchange reserves to limit exchange rate volatility [21,22].

Using data from five well-known Far East countries (China, Japan, Taiwan, Hong Kong, and Korea), this study analyzes the relationship between changes in international exchange reserves and foreign exchange rate movements. We particularly investigate what monetary authorities in each country are driving change their international exchange reserves. As we present in Section 2, the changes in international exchange reserves are explained by several motives, mainly mercantilism motive and precautionary motive, etc. Also, our analysis contains the confirmation of the sterilized and unsterilized policy of the monetary authority.

To grasp the details of the relationship between changes in international exchange reserves and foreign exchange rate movements, we apply quantile Granger causality and quantile regression analysis. Since the demand for foreign currency reserves by monetary authorities varies depending 
on the conditional distribution of the reserves, the level of foreign reserves is as important as other determinants for reserves demand [23]. Utilizing the quantile analysis advantage, namely, its ability to provide information about upper and lower tail-dependence, this study identifies the asymmetric effects of exchange rates on foreign exchange reserves. In other words, the characteristics of each quantile that can be diluted in the general Granger causal analysis are identified by separating them in the quantile Granger causal analysis.

The rest of this paper consists of four sections. Section 2 reviews the previous theoretical and empirical literature on the motives for accumulating foreign exchange reserves. Section 3 describes the method of quantile Granger causality and quantile regression. Section 4 presents the sample data and investigates the empirical analysis results. Section 5 presents the conclusion of this study.

\section{Literature Review on the Accumulation of Foreign Exchange Reserves}

Calvo and Reinhart [8] investigated whether countries claiming to be floating are actually doing so. They found that most countries that say they allow their exchange rate to float do not, and confirmed that there are epidemic cases of "fear of floating," such as a fear of large currency swings. They suggest that the fear of floating phenomenon is widespread among emerging market countries and cuts across regions and levels of development. Dutta and Leon [24] investigated the effects of official intervention on real exchange rate movements by using data for 27 advanced and emerging market economies and found evidence of a "dread of depreciation" in almost all countries. The result implies that the monetary authorities actively intervene when real exchange rates depreciate. Contrastively, Levy-Yeyati et al. [25] revealed that in most cases, interventions were aimed at limiting appreciations rather than depreciations, and were often motivated from the neo mercantilist point of view of depreciated real exchange rate to protect domestic industries. They showed that a depreciation in exchange rate lead to higher growth, but rather than working through import substitutions or export booms, as argued from the mercantilist point of view, its effects primarily works through deepening domestic savings and capital accumulation.

Holding foreign exchange reserves results in costs [26-31]. Rodrik [29] estimated that the cost of accumulating foreign exchange reserves was approximately $1 \%$ of the GDP in developing countries. Gallagher and Shrestha [32] reported that the figure was more than $1.8 \%$ of the GDP in developing countries and 3\% in China. The yield on foreign exchange reserves is much lower than the government's financing costs for borrowing in local currency or dollars. However, policymakers and scholars argue that the economic cost of holding foreign reserves is lower than the financial impact of an economic crisis [33].

On the theoretical side, the motive for stockpiling foreign exchange reserves can be explained from two perspectives. The first point of view is based on the modern mercantilism perspective, explaining that the hoarding of international reserves is a part of a deliberate development strategy, i.e., an outward-oriented growth strategy, which facilitates growth by maintaining an undervalued real exchange rate to maintain a country's export competitiveness [34-40]. Among others, Dooly et al. [38] argued that China's export-driven growth is supported by official capital outflow through yuan (Renminbi) undervaluation, capital control, and the accumulation of foreign exchange reserves. Foreign exchange reserves function to promote exports, create better jobs, and absorb abundant labor in traditional sectors such as agriculture. The low valuation of the local currency for this purpose occurs in most East Asian countries [34,35]. Srinivasan et al. [40] showed that concerns about India's export competitiveness seems to have contributed to a large stockpile of reserves. Srinivasan and Kumar [41] found that when intervening, the Reserve Bank of India (RBI) responded much more strongly to appreciating pressure than to depreciating pressure and that such a policy response accounted for the large build-up in foreign exchange reserves. Delatte and Fouquau [37] found evidence that after 2000 , mercantilist motives were the major driver of the accumulation of foreign exchange reserves by emerging countries. 
An alternative explanation for the hoarding of international reserves is the self-insurance/ precautionary motive, explained as the view that as output stabilizers, international reserves can reduce sovereign risk [42]. International reserves can bring down the probability of an output drop induced by capital flight and/or can decrease the depth of the output collapse when the sudden stop happens. Similar views have been presented by using more elaborate models [23,33,34,43-50]. These studies concluded that some of the large increase in international reserves were consistent with self-insurance motives for the sudden-stop risks. Among others, Aizenman and Marion [33] explored the interpretation of the relatively high demand for international reserves in the Far East countries and the relatively low demand in other developing countries. They showed that in the aftermath of the 1997 Asian financial crisis, countries that had to deal with higher perceived sovereign risk and higher fiscal liabilities opted to increase their demand for reserves. García and Soto [45] estimated the optimal reserve level for the East Asian economies and for Chile and concluded that the current reserve inventory for most cases were consistent with the optimal self-insurance policy. Aizenman and Lee [34] found that empirical evidence supports precautionary motives in accounting for the patterns of hoarding reserves for most countries, including China. The results suggest that when the economy is vulnerable to sudden rigidity, there are many preventive demands for international reserves with their own insurance to avoid costly liquidation of long-term projects. Korinek and Servén [48] pointed out the welfare effects of foreign exchange reserves accumulation and real exchange rate undervaluation in an intertemporal setting: static welfare loss experienced when reserve accumulation sacrifices current domestic spending and dynamic welfare benefits experienced when reserve accumulation increases. They explained that the accumulation of reserves could be a form of preventive saving to prepare for future country-specific adverse impacts.

In addition to these two main motivations, there are studies claiming that increasing the supply of financial assets [51] and financial integration [44] are motivations for stockpiling foreign exchange reserves. Recently, financial stability incentives have been pushing countries to stockpile foreign currency reserves to limit losses after the onset of a financial crisis, through providing a sufficiently large "buffer stock" [46,52]. As Lane and Burke [53] pointed out, during the Asian financial crisis, countries with large reserves of foreign exchange reserves (such as Singapore and Taiwan) were less strongly affected. Obstfeld et al. [50] showed that financial stability and financial openness are important factors that can explain the rapid growth of international reserves in the emerging markets.

\section{Methodology}

In our empirical analysis, we employ the general Granger causality (Granger causality in mean) and the Quantile Granger causality test (Granger causality in quantile). Let explanatory vector $I_{t} \equiv\left(I_{t}^{X}, I_{t}^{W}\right)^{\prime} \in R^{s+q}$, where $X_{t}$ and $W_{t}$ are strictly stationary time series processes with a past information set $I_{t}^{X}=\left(X_{t-1}, \cdots, X_{t-s}\right)^{\prime} \in R^{s}$ and $I_{t}^{W}=\left(W_{t-1}, \cdots, W_{t-q}\right)^{\prime} \in R^{q}$, respectively. According to Granger [14], if a past $W_{t}$ does not help to predict a future $X_{t}$, given the past $X_{t}$, it means that a series $W_{t}$ does not Granger cause another series $X_{t}$. The null hypothesis of Granger non-causality in a distribution from $W_{t}$ to $X_{t}$ is the following Equation (1).

$$
H_{0}^{W \nrightarrow X}: F_{X}\left(x \mid I_{t}^{X}, I_{t}^{W}\right)=F_{X}\left(x \mid I_{t}^{X}\right), \text { for all } x \in R
$$

where $F_{X}\left(\cdot \mid I_{t}^{X}, I_{t}^{W}\right)$ and $F_{X}\left(\cdot \mid I_{t}^{X}\right)$ are the conditional distribution functions of $X_{t}$, given $\left(I_{t}^{X}, I_{t}^{W}\right)$ and $\left(I_{t}^{X}\right)$, respectively. Because of the complexity of estimating the conditional distribution, the test of Granger non-causality in mean, called the general Granger non-causality test, has been mainly proposed in many papers. The null hypothesis of Granger non-causality in mean from $W_{t}$ to $X_{t}$ is the following Equation (2).

$$
H_{0}^{\mathrm{C}: W \rightarrow X}: E\left(X_{t} \mid I_{t}^{X}, I_{t}^{W}\right)=E\left(X_{t} \mid I_{t}^{X}\right), \text { for all } X_{t} \in R
$$

where $E\left(X_{t} \mid I_{t}^{X}, I_{t}^{W}\right)$ and $E\left(X_{t} \mid I_{t}^{X}\right)$ are the means of $F_{X}\left(\cdot \mid I_{t}^{X}, I_{t}^{W}\right)$ and $F_{X}\left(\cdot \mid I_{t}^{X}\right)$, respectively. 
However, the test for Granger non-causality in mean is only a necessary condition for Equation (1); therefore, its application may be limited if it is a distribution-dependent series. Thus, we consider the test for Granger non-causality in conditional quantiles. Let $Q_{\tau}^{X, W}\left(\cdot \mid I_{t}^{X}, I_{t}^{W}\right)$ be the $\tau$-quantile of $F_{X}\left(\cdot \mid I_{t}^{X}, I_{t}^{W}\right)$. Then, Equation (1) can be rewritten as Equation (3) as follows:

$$
H_{0}^{Q C: W \nrightarrow X}: Q_{\tau}^{X, W}\left(X_{t} \mid I_{t}^{X}, I_{t}^{W}\right)=Q_{\tau}^{X}\left(X_{t} \mid I_{t}^{X}\right), \text { for all } X_{t} \in R, \tau \in T
$$

where $T$ is a compact set, $T \subset[0,1]$, the conditional $\tau$-quantile of $X_{t}$ satisfies the following restrictions in Equation (4).

$$
\begin{gathered}
\operatorname{Pr}\left\{X_{t} \leq Q_{\tau}^{X, W}\left(X_{t} \mid I_{t}^{X}, I_{t}^{W}\right) \mid I_{t}^{X}, I_{t}^{W}\right\} \tau, \operatorname{Pr}\left\{X_{t} \leq Q_{\tau}^{X}\left(X_{t} \mid I_{t}^{X}\right) \mid I_{t}^{X}\right\} \tau \\
\text { for all } X_{t} \in R, \tau \in T
\end{gathered}
$$

When an explanatory vector $I_{t}$ is given, $\operatorname{Pr}\left\{X_{t} \leq Q_{\tau}^{X}\left(X_{t} \mid I_{t}^{X}\right) \mid I_{t}^{X}\right\}$ is equal to $E\left(1\left[X_{t} \leq Q_{\tau}^{X}\left(X_{t} \mid I_{t}^{X}\right)\right] \mid I_{t}^{X}\right)$, and $1\left[X_{t} \leq x\right]$ is an indicator function of the event that $X_{t} \leq x$. Thus, the null hypothesis of Granger non-causality in quantile from $W_{t}$ to $X_{t}$ is written in Equation (5) as follows:

$$
\begin{gathered}
H_{0}^{Q C: W \nrightarrow X}: E\left(1\left[X_{t} \leq Q_{\tau}^{X, W}\left(X_{t} \mid I_{t}^{X}, I_{t}^{W}\right)\right] \mid I_{t}^{X}, I_{t}^{W}\right)=E\left(1\left[X_{t} \leq Q_{\tau}^{X}\left(X_{t} \mid I_{t}^{X}\right)\right] \mid I_{t}^{X}\right) \\
\text { for all } X_{t} \in R, \tau \in T
\end{gathered}
$$

Following Troster [54], we assume that $Q_{\tau}\left(\cdot \mid I_{t}\right)$ is specified by a parametric quantile model $z(\cdot, \theta(\tau))$ belonging to functions $Z=\left\{z(\cdot, \theta(\tau)) \mid \theta(\cdot): \tau \rightarrow \theta(\tau) \in \Theta \in R^{p}\right.$, for $\left.\tau \in T \subset[0,1]\right\}$. We can rewrite the null hypothesis of Granger non-causality in quantile in Equation (5) as the following Equation (6):

$$
\begin{gathered}
H_{0}^{\mathrm{QC}: W \nrightarrow X}: E\left(1\left[X_{t} \leq z\left(I_{t}^{X}, \theta_{0}(\tau)\right] \mid I_{t}^{X}, I_{t}^{W}\right)=\tau\right. \text { or } \\
H_{0}^{\mathrm{QC}: W \nrightarrow X}: E\left(1\left[X_{t}-z\left(I_{t}^{X}, \theta_{0}(\tau) \leq 0-\tau\right] \mid I_{t}^{X}, I_{t}^{W}\right)=0\right. \\
\quad \text { for all } X_{t} \in R, \tau \in T
\end{gathered}
$$

By applying the test of Granger causality in quantile in Equation (6), it is possible to understand and interpret the relations between the variables according to the quantiles, which could not be captured in the test of Granger causality in mean in Equation (2). So, if we confirm the causal relationship for the changes of two variables, the closer the quantile is to 0 , the more it means the causality in the rapid decrease in the changes, and the closer the quantile is to 1 , the more it means the causality in the rapid increase in the changes. Therefore, the causal relationship in quantile allows us to capture the asymmetric causality of the magnitude of the changes.

Let $\Psi$ be a $T \times n$ matrix with element $\psi_{i, j}=\Psi_{\tau_{j}}\left(X_{i}-z\left(I_{i}^{X}, \theta_{T}\left(\tau_{j}\right)\right)\right)$, where $\Psi_{\tau_{j}}(\cdot)$ is the function $\Psi_{\tau_{j}}(\varepsilon) 1(\varepsilon \leq 0)-\tau_{j}$. The test statistic proposed by Troster [54] is written Equation (7) as follows:

$$
S_{T}=\frac{1}{T n} \sum_{j=1}^{m}\left|\psi_{\cdot j}^{\prime} Y \psi \cdot j\right|,
$$

where $\mathrm{Y}$ is $T \times T$ matrix with element $v_{t, S}=\exp \left[-0.5\left(I_{t}-I_{S}\right)^{2}\right]$ and $\psi_{\cdot j}^{\prime}$ denotes the $\mathrm{j}$-th column of $\Psi$. The test statistic $S_{T}$ is calculated by the subsampling procedure of Troster [54]. Under the null hypothesis of Granger non-causality in quantile in Equation (6), we apply three different quantile autoregressive (QAR) models $z(\cdot)$ for all $\tau \in T \subset[0,1]$ as the following Equation (8) and calculate the test statistic in Equation (7).

$$
\operatorname{QAR}(1): z^{1}\left(I_{t}^{X}, \theta(\tau)\right)=\mu_{1}(\tau)+\mu_{2}(\tau) X_{t-1}+\sigma_{t} \Phi_{u}^{-1}(\tau),
$$




$$
\begin{gathered}
\operatorname{QAR}(2): z^{2}\left(I_{t}^{X}, \theta(\tau)\right)=\mu_{1}(\tau)+\mu_{2}(\tau) X_{t-1}+\mu_{3}(\tau) X_{t-2}+\sigma_{t} \Phi_{u}^{-1}(\tau), \\
\operatorname{QAR}(3): z^{3}\left(I_{t}^{X}, \theta(\tau)\right)=\mu_{1}(\tau)+\mu_{2}(\tau) X_{t-1}+\mu_{3}(\tau) X_{t-2}+\mu_{4}(\tau) X_{t-3}+\sigma_{t} \Phi_{u}^{-1}(\tau),
\end{gathered}
$$

where $\Phi_{u}^{-1}$ is the inverse of a standard normal distribution function and $\theta(\tau)$ denotes the vector of parameters $\left(\mu_{1}(\tau), \mu_{2}(\tau), \mu_{3}(\tau), \mu_{4}(\tau), \sigma_{t}\right)^{\prime}$ estimated by maximum likelihood in an equally spaced grid of quantiles. If we use monthly data, QAR(1), QAR(2), and QAR(3) mean that the time lag is 1, 2, and 3 months, respectively.

We use the quantile regression model as a continuation of the quantile Granger causal analysis. The sign of the quantile causal relationship between two variables is estimated by the QAR(3) in Equation (8) including the lagged variables of another variable as the following Equation (9):

$$
Q_{\tau}^{X}\left(X_{t} \mid I_{t}^{X}, I_{t}^{W}\right)=\mu_{1}(\tau)+\mu_{2}(\tau) X_{t-1}+\mu_{3}(\tau) X_{t-2}+\mu_{4}(\tau) X_{t-3}+\beta(\tau) W_{t-1}+\sigma_{t} \Phi_{u}^{-1}(\tau)
$$

If the estimated coefficient $\beta(\tau)$ is positive (+), it means that an increase (decrease) in $W_{t}$ leads to an increase (decrease) in $X_{t}$. Conversely, if the estimation coefficient is negative (-), it means that an increase (decrease) in $W_{t}$ leads to a decrease (increase) in $X_{t}$.

\section{Empirical analysis}

\subsection{Sample Data}

We analyze the monthly data of the Far East (China, Japan, Taiwan, Hong Kong, and Korea) countries for the period from January 1997 to April 2020. As of May 2020, these five countries are among the world's top 10 foreign exchange reserves [55]. The international exchange reserves and U.S. bilateral nominal exchange rates were retrieved from FRED, the database of the Federal Reserve Bank of St. Louis [56]. In the empirical analysis of this study, we use the U.S. dollar bilateral exchange rate because the share of U.S. dollar holdings in global foreign exchange reserves was $60.9 \%$ in 2019 , followed by the Euro at 20.5\% [57]. The nominal effective exchange rates sourced from the Bank for International Settlements (BIS) [58], which are available as monthly averages $(2010=100)$. In detail, U.S. bilateral nominal exchange rates are the nominal exchange rates of the Chinese Yuan, Japanese Yen, New Taiwan Dollar, Hong Kong Dollar, and Korean Won per U.S. dollar. Thus, an increase in the nominal exchange rates indicates a depreciation of the country's currency and an appreciation of the U.S. dollar. The nominal exchange rate is limited in that it represents only the exchange rate of two currencies, while the nominal effective exchange rate, expressed in U.S. dollars, is a weighted average of the exchange rate obtained by using trade weights for various countries. An increase in the nominal effective exchange rate means an appreciation of the country's currency, and to measure the international price competitiveness of a country, the nominal effective exchange rate is considered more appropriate than the nominal exchange rate.

Appendix A Table A1 presents the descriptive statistics of the returns (i.e., \% changes) series. The means of the FX rate (nominal exchange rates) returns are negative for China and Japan, and the means of the NEER (nominal effective exchange rates) returns are negative for Taiwan and Korea. Only in Hong Kong are the means of both exchange rate returns positive. The means of RES (international exchange reserves) returns are positive for all countries. Except for China, the signs of the FX rate and NEER's skewness are reversed. The FX rate and the NEER are exchange rates expressed in the country's own currency and in dollars, respectively; therefore, these results are generally natural. RES distributions are skewed to the right (skewness $<0$ ), except for Hong Kong and Korea. The distributions of the three variables for all countries are highly leptokurtic (kurtosis $>3$ ), excluding China's RES. The high kurtosis of the distributions implies a significant possibility of fluctuations in the variables located near the tail and further away from the mean. In addition, making quantile analysis more appropriate, it suggests that the relationship between international reserves and exchange rates may vary at each different point of the conditional distribution. The results of the Jarque-Bera test $\left(J-B \chi^{2}\right)$ for normality show the null hypothesis of a normal distribution is rejected, 
except for China's international reserves. The correlation between the FX rate and RES is negative for all countries. However, the correlation between the NEER and RES was negative (-) for China and Hong Kong, and positive (+) for Japan, Taiwan, and Korea. Further analysis needs to be made for these differences.

Figure 1 plots the monthly percentage changes (\%) in the FX rate (nominal exchange rates), the NEER (nominal effective exchange rates in U.S. dollar), and RES (foreign exchange reserves). For all countries except China, the three variables exhibit a pattern of convergence over time. As shown in the figures, volatility persisted in China and Japan, even though the three series became less volatile after 2000. In addition, very high volatility emerged in the Asian financial crisis of 1999 and after the global financial crisis of 2008 in Hong Kong and Korea.

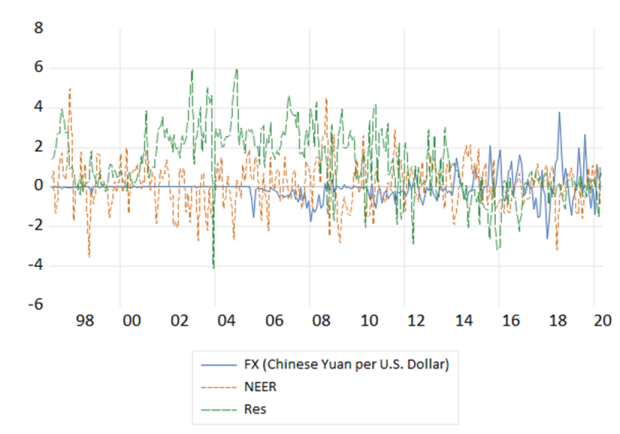

(a) China

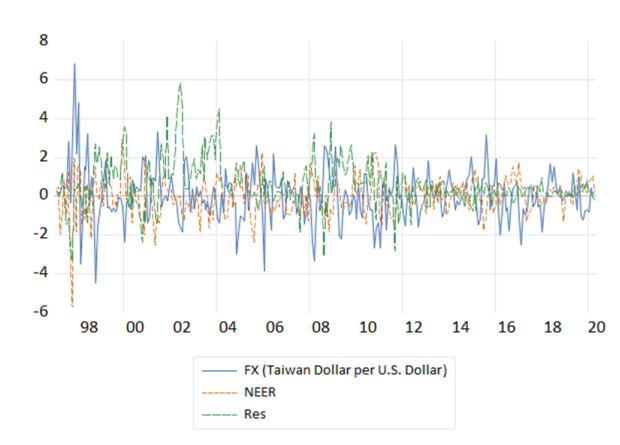

(c) Taiwan

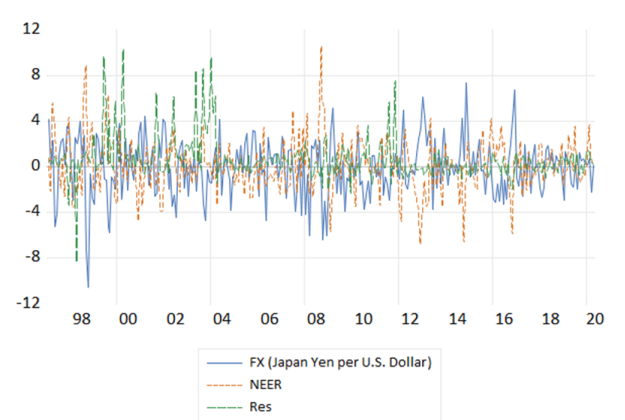

(b) Japan

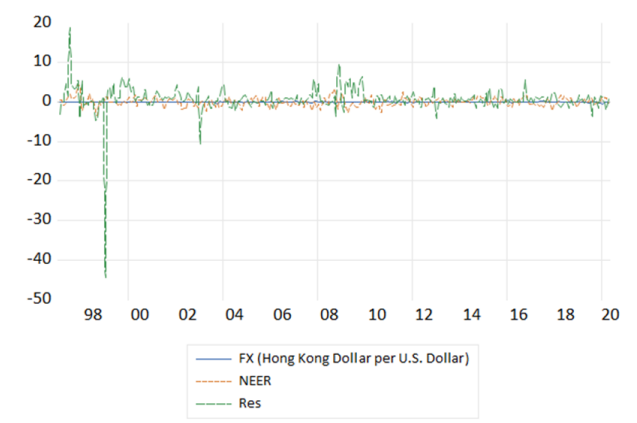

(d) Hong Kong

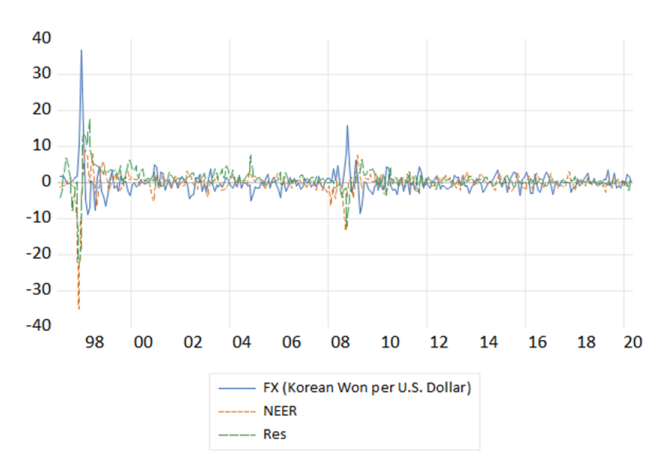

(e) Korea

Figure 1. Dynamics of international reserves and foreign exchange rates for (a) China, (b) Japan, (c) Taiwan, (d) Hong Kong, and (e) Korea. 
Table 1 summarizes the results of the unit root tests for the log level and the percentage (\%) changes in the sample series. The null hypothesis of a unit root is tested by using an augmented Dickey-Fuller (ADF) with break (DF_Break) test suggested by Perron [41] and Perron and Vogelsang [59,60] and the PP test of Phillips and Perron [61]. The DF_Break test can overcome the weakness of the ADF test, which has limited power in distinguishing the unit root null hypothesis from the trend stationary alternative, and the PP test is based on a nonparametric method of controlling for serial correlation when testing for a unit root. The results in Table 2 reveal that all series are stationary.

Table 1. Unit root tests.

\begin{tabular}{|c|c|c|c|c|c|c|}
\hline & \multicolumn{2}{|c|}{ FX rate } & \multicolumn{2}{|c|}{ NEER } & \multicolumn{2}{|c|}{ Res } \\
\hline & DF_Break & PP & DF_Break & PP & DF_Break & PP \\
\hline \multicolumn{7}{|c|}{ Panel A: log level } \\
\hline China & -2.6105 & -0.3083 & -3.7046 & -2.1808 & -3.3216 & 0.9943 \\
\hline Japan & -3.8312 & -1.8744 & -3.8429 & -2.6156 & 0.0098 & -0.6691 \\
\hline Taiwan & -4.8314 & 0.3079 & -4.7049 & -1.0805 & -4.4674 & -0.4097 \\
\hline $\begin{array}{l}\text { Hong } \\
\text { Kong }\end{array}$ & -3.5847 & -2.8151 & -4.4371 & -1.8725 & -4.3843 & -2.3160 \\
\hline Korea & -3.6834 & 0.5797 & -3.5087 & -0.4787 & -2.6084 & -1.6579 \\
\hline \multicolumn{7}{|c|}{ Panel B: \% changes } \\
\hline China & $-11.0780^{* * *}$ & $-9.7466^{* * *}$ & $-11.9644^{* * *}$ & $-11.3113^{* * *}$ & $-11.8585^{* * *}$ & $-11.0664^{* * *}$ \\
\hline Japan & $-13.5555^{* * *}$ & $-12.6702^{* * *}$ & $-13.2861^{* * *}$ & $-12.3308^{* * *}$ & $-14.4436^{* * *}$ & $-13.8503^{* * *}$ \\
\hline Taiwan & $-12.3670^{* * *}$ & $-10.9003^{* * *}$ & $-14.1362^{* * *}$ & $-12.3854^{* * *}$ & $-13.7416^{* * *}$ & $-12.9082^{* * *}$ \\
\hline $\begin{array}{l}\text { Hong } \\
\text { Kong }\end{array}$ & $-14.0329^{* * *}$ & $-13.0750^{* * *}$ & $-11.9612^{* * *}$ & $-11.1574^{* * *}$ & $-24.8354^{* * *}$ & $-16.0923^{* * *}$ \\
\hline Korea & $-15.9090^{* * *}$ & $-9.6270^{* * *}$ & $-17.0192^{* * *}$ & $-9.7006^{* * *}$ & $-12.4709^{* * *}$ & $-9.3397^{* * *}$ \\
\hline
\end{tabular}

Notes: See the notes of Appendix A Table A1. The null hypothesis of the DF_Break and PP tests is that the series are non-stationary. ${ }^{* * *}$ indicates the rejection of the null hypothesis at the $1 \%$ significance level. FX rate, nominal exchange rate; NEER, nominal effective exchange rates; Res, international exchange reserves.

Table 2. Johansen linear cointegration test.

\begin{tabular}{|c|c|c|c|c|c|}
\hline & \multirow[b]{2}{*}{ Test Statistic } & \multicolumn{2}{|c|}{$\log (\mathrm{RES})$ and $\log (\mathrm{FX}$ rate $)$} & \multicolumn{2}{|c|}{$\log (\mathrm{RES})$ and $\log (\mathrm{NEER})$} \\
\hline & & $H_{0}:$ rank $=0$ & $H_{0}:$ rank $=1$ & $H_{0}:$ rank $=0$ & $H_{0}:$ rank $=1$ \\
\hline \multirow{2}{*}{ China } & Trace & 15.04 & 2.45 & $21.89 *$ & 1.90 \\
\hline & Max. eigenvalue & 12.58 & 2.45 & $19.99 *$ & 1.90 \\
\hline \multirow{2}{*}{ Japan } & Trace & 10.80 & $4.29 *$ & 14.13 & $4.72 *$ \\
\hline & Max. eigenvalue & 6.51 & $4.29 *$ & 9.41 & $4.72 *$ \\
\hline \multirow{2}{*}{ Taiwan } & Trace & $31.63 *$ & 1.93 & 18.49 & 3.70 \\
\hline & Max. eigenvalue & $29.70 *$ & 1.93 & 14.79 & 3.70 \\
\hline Hong & Trace & 8.82 & 0.86 & 8.54 & 0.67 \\
\hline Kong & Max. eigenvalue & 7.96 & 0.86 & 7.86 & 0.67 \\
\hline \multirow{2}{*}{ Korea } & Trace & $42.41 *$ & $13.28 *$ & $47.69 *$ & 11.42 \\
\hline & Max. eigenvalue & $29.13 *$ & $13.28 *$ & $36.27 *$ & 11.42 \\
\hline
\end{tabular}

Notes: See the notes of Appendix A Table A1. The null hypothesis is no cointegration. * indicates the rejection of the null hypothesis at the $5 \%$ critical value.

Table 2 presents the results of the Johansen linear cointegration test of log level variables for the FX rate and RES and the NEER and RES. The cointegration test proposed by Johansen $[62,63]$ allows the identification of the linear cointegration relationship between an I(1) variable with a unit root. Each variable is unstable with a unit root, $\mathrm{I}(1)$, but if their linear combinations show stability without unit roots, $\mathrm{I}(0)$, it is defined as a linear cointegration relationship between the two variables. As shown in Table 2, since not all log level variables in the five countries have a cointegration relationship, we proceed with further analysis by using differential variables. 


\subsection{Empirical Results}

The relationship between international reserves and foreign exchange rates may vary depending on the country's economic situation and policy intent. In the traditional theory of monetary policy, if the monetary authority changes the amount of money in the market as opposed to increasing or decreasing its international reserves, the value of that country's currency changes; this strategy is called the unsterilized policy. However, if the monetary authority responds to changes of reserves in a different way, such as through government bonds rather than through changes in the amount of money, it may not affect the value of its own currency. In this situation, the monetary authority uses a sterilized policy. Thus, if the change in international reserves does not affect the foreign exchange rate, it can be interpreted that the monetary authority has successfully intervened by using the sterilized policy. However, even if the monetary authority changes international reserves to stabilize the value of its own currency, changes in the value of its currency cannot be prevented, especially when foreign investment funds are rapidly leaked due to negative economic situations or expectations. During the financial crisis in East Asia in the late 1990s, major Asian countries experienced severe shortages in reserves and a sharp decline in the value of their currencies.

In some cases, changes in the foreign exchange rates may cause changes in reserves, and the effect of the changes in exchange rates on changes in the reserves may be reversed depending on the country's economic situation or the intervention of its monetary authority. In the traditional theory of an open economy, a decrease in the value of the domestic currency can lead to an increase in export and economic growth, but thereafter, pressure on the appreciation of the currency rises. At that time, if the monetary authority wants its currency value to remain at the same low level as before, depreciation can be induced by an intended intervention, called mercantilist interventions, that increases international reserves and simultaneously increases the amount of money. On the other hand, international reserves may decrease after exchange rate declines, and the monetary authority may actively intervene to stabilize its currency value. In this case, the monetary authorities' intervention aims to keep the monetary value of its currency at an appropriate level. This intervention against "fear of floating" may be particularly strong in the negative economic situation where the decline in monetary value can last for a considerable period of time. Therefore, understanding the relationship between the exchange rate movements and the changes in international reserves requires a comprehensive consideration of whether the causal relationship is established and the direction and sign of the relationship.

Table 3 shows the results of the general causality test (Granger causality in mean) proposed by Granger [14]. At lags 1 and 2, in China, the change in international reserves significantly Granger causes the nominal exchange rate change at lags 1 and 2, but at most lags, no significant causal relationship is found between the changes in reserves and nominal exchange rate movements. In the case of Japan, the change in international reserves significantly Granger caused the change of the nominal exchange rate only when the lags are 24. Taiwan has a uni- or bi-directional Granger causal relationship between the changes in variables at most lags. In Hong Kong, the change in the nominal effective exchange rate significantly Granger causes the change in international reserves at lags 3, 6, and 12. At all lags except lag 24, Korea has a bi-directional Granger causal relationship between the changes in variables.

Meanwhile, the results of the general Granger causal relationship of China and Japan show that exchange rate changes do not significantly cause changes in their foreign exchange reserves; therefore, it is difficult to grasp the possibility of a mercantilist motive by the monetary authorities in the two countries.

However, as suggested in previous studies, major Asian countries are suspected of maintaining a depreciation of their currencies by the deliberate intervention of their monetary authorities to grow their economies and, especially, to increase their export-led economic growth. Since the intention of the monetary authority may vary depending on the level of international reserves and exchange rates, it is necessary to take into account the characteristics of quantiles that are not captured in the general Granger causality test. Thus, by using a quantile analysis, we analyze the relationship between 
changes in international reserves and exchange rate movements in five countries and systematically grasp the intentions of the monetary authority to intervene in the market.

Table 3. Granger causality test between the \% change of reserves and FX rate (and NEER).

\begin{tabular}{|c|c|c|c|c|c|}
\hline & \multirow{2}{*}{ Lag } & \multicolumn{2}{|c|}{ RES and FX rate } & \multicolumn{2}{|c|}{ RES and NEER } \\
\hline & & RES $\nRightarrow$ FX Rate & RES $\nLeftarrow$ FX Rate & $\mathrm{RES} \nRightarrow$ NEER & $\mathbf{R E S} \nLeftarrow \mathbf{N E E R}$ \\
\hline \multirow{6}{*}{ China } & 1 & $5.1442 * *$ & 0.4259 & 0.2143 & 1.1937 \\
\hline & 2 & $2.6269 *$ & 0.0192 & 2.0098 & 0.9226 \\
\hline & 3 & 1.9727 & 0.3146 & 1.2990 & 0.7693 \\
\hline & 6 & 1.3415 & 0.2594 & 0.8076 & 0.2309 \\
\hline & 12 & 0.7054 & 0.7505 & 0.8476 & 1.1771 \\
\hline & 24 & 0.7226 & 0.6952 & 0.8333 & 1.0735 \\
\hline \multirow{6}{*}{ Japan } & 1 & 2.4976 & 1.5510 & 0.4612 & 1.8543 \\
\hline & 2 & 1.1288 & 1.0369 & 0.5139 & 1.1132 \\
\hline & 3 & 0.8623 & 1.1218 & 0.4753 & 0.7244 \\
\hline & 6 & 1.0129 & 0.6628 & 0.6047 & 0.5214 \\
\hline & 12 & 0.9118 & 0.7851 & 0.6625 & 0.6065 \\
\hline & 24 & $1.6070^{* *}$ & 0.7683 & 1.3260 & 0.8236 \\
\hline \multirow{6}{*}{ Taiwan } & 1 & 1.1356 & $5.1212 * *$ & $10.4280^{* * *}$ & 1.5418 \\
\hline & 2 & $3.0349 * *$ & $3.2393 * *$ & $5.7021^{* * *}$ & $2.9235 *$ \\
\hline & 3 & 2.1099 * & 2.0039 & $3.7513^{* *}$ & $2.8496^{* *}$ \\
\hline & 6 & $2.8607^{* *}$ & 1.0084 & $2.8757^{* * *}$ & 1.8554 * \\
\hline & 12 & $2.5790 * * *$ & $1.6668 *$ & 1.2917 & 1.4509 \\
\hline & 24 & 1.2747 & $1.7662^{* *}$ & 1.2153 & 2.0896 ** \\
\hline \multirow{6}{*}{ Hong Kong } & 1 & 0.7690 & 0.1074 & 0.8897 & 1.8437 \\
\hline & 2 & 0.9028 & 0.2115 & 0.8284 & 1.1520 \\
\hline & 3 & 0.8492 & 0.6848 & 0.7583 & $3.5439 * *$ \\
\hline & 6 & 0.4356 & 0.8485 & 0.4380 & $2.6016^{* *}$ \\
\hline & 12 & 0.6045 & 0.5643 & 0.5408 & $4.4086^{* * *}$ \\
\hline & 24 & 0.3808 & 1.3789 & 1.0899 & 1.3244 \\
\hline \multirow{6}{*}{ Korea } & 1 & $70.037^{* * *}$ & $21.170 * * *$ & $63.050 * * *$ & $20.453 * * *$ \\
\hline & 2 & $28.937^{* * *}$ & $7.2478^{* * *}$ & $26.147^{* * *}$ & $7.1094^{* * *}$ \\
\hline & 3 & $25.268^{* * *}$ & $20.297^{* * *}$ & $23.767^{* * *}$ & $18.802^{* * *}$ \\
\hline & 6 & $15.873 * * *$ & $8.5854^{* * *}$ & $14.516^{* * *}$ & $9.5634^{* * *}$ \\
\hline & 12 & $2.5119 * * *$ & $4.8407^{* * *}$ & $2.8236^{* * *}$ & $4.4607^{* * *}$ \\
\hline & 24 & 1.1608 & $2.0358 * * *$ & 0.9982 & $1.7646^{* *}$ \\
\hline
\end{tabular}

Notes: See the notes of Appendix A Table A1. The null hypothesis is Granger non-causality. The figures are the F-statistics for the Granger causality test. * ${ }^{* *}$, and *** indicate the rejection of the null hypothesis at the $10 \%, 5 \%$, and $1 \%$ significance levels, respectively.

Appendix B Tables A2-A6, show the results of the quantile Granger causality (Granger causality in quantile) of the five Far Eastern countries. Considering $\tau=\{$ all $\}$, both the changes in the nominal exchange rate and the nominal effective exchange rate in all five countries Granger cause changes in each country's international reserves at the $1 \%$ of significant level. In detail, however, the change in each country has different characteristics according to the quantiles of the distribution.

In Appendix B Table A2, for the quantiles $\tau=\{$ all, 0.25, 0.30 $\}$ at lags 1, 2, and 3, both the changes in the nominal exchange rate and the nominal effective exchange rate in China significantly Granger cause a change in Chinese foreign exchange reserves. The fact that China's exchange rates significantly quantile Granger cause changes in its reserves is also seen at the extreme tail of the conditional distribution, $\tau=\{0.85\}$ at lag 3 . This indicates the possibility of Chinese monetary authority's policy intervention against the fluctuations in the foreign exchange market. Overall, however, there are more quantiles where the changes in the exchange rates in China do not Granger cause changes in the international reserves. On the other hand, the changes in the Chinese international reserves are more significant in relation to the changes in its nominal exchange rate than to the changes in its 
nominal effective exchange rate. The fact that the changes in international reserves have little effect on the nominal effective exchange rate means that the monetary authority's policy of sterilization is working effectively.

Appendix B Table A3 shows the result of the quantile Granger causal relationship between the Japanese exchange rate and its international reserves. At the quantiles of the conditional distributions, $\tau=\{0.05$ to 0.35$\}$ or $\tau=\{0.50$ to 0.90$\}$ when the lags are 1,2 , and 3 , the changes in the nominal exchange rate and nominal effective exchange rate in Japan significantly quantile cause the changes in Japanese foreign reserves. Therefore, it can be interpreted that there has been Japanese monetary authority intervention in most exchange rate changes, except for the medium level $(\tau=\{0.40,0.45\})$ and the extreme high tail level $(\tau=\{0.95\})$ quantiles. The changes in Japanese international reserves do not cause the changes in exchange rates in any quantiles of the distribution, which means the sterilized policy by Japanese monetary authority is effectively being applied in the money market.

As shown in Appendix B Table A4, the changes in the nominal exchange rate and the nominal effective exchange rate in Taiwan are found to significantly cause changes in Taiwan's foreign exchange reserves in the quartile ranges $\tau=\{0.15$ to 0.30$\}$ or $\tau=\{0.55$ to 0.75$\}$ at lags 1,2 , and 3 . Therefore, it can be seen that Taiwan's policy intervention appears when the changes in the exchange rate exceed a specified range, $\tau=\{0.35$ to 0.40$\}$. For the extreme tails of the distribution on both sides, it is possible that they reflect mercantilist intervention attempts, the results of which did not produce significant changes. In addition, when the lags are 1 and 2, the change in Taiwan's international reserves significantly cause the nominal effective exchange rate change at the quantiles of tails $\tau=\{0.10,0.80,0.90\}$, which indicate the tail-dependent property of quantile analysis. Moreover, in the wider range of quantiles, the changes in Taiwan's international reserves significantly cause changes in the nominal exchange rate.

Appendix B Table A5 shows the results of the quantile granger causality analysis in Hong Kong. Except for the quantile $\tau=\{0.25\}$, the changes in foreign exchange reserves in Hong Kong does not significantly cause the changes in the nominal effective exchange rates. Therefore, it can be interpreted that the stabilization policy of Hong Kong's monetary authority, which defended the changes in its currency value, is well reflected. However, the high fluctuations in the foreign exchange reserves in Hong Kong quantile Granger cause changes in the nominal exchange rate of Hong Kong at the edges of the distribution, $\tau=\{0.15$ to 0.25$\}$ or $\tau=\{0.70$ to 0.90$\}$. The null hypothesis of quantile Granger non-causality from the exchange rates to the international reserves is significantly rejected in the ranges of quantiles $\tau=\{0.05$ to 0.40$\}$ or $\tau=\{0.55$ to 0.95$\}$ when the lags are 1 and 3 , and in the ranges of quantiles $\tau=\{0.05$ to 0.40$\}$ or $\tau=\{0.55$ to 0.90$\}$ when the lags are 2 . This shows the possibility of Hong Kong's monetary authority intervening extensively in response to the changes in its exchange rates.

In the case of Korea, in Appendix B Table A6, the null hypothesis of quantile Granger non-causality from the changes in Korean international reserves to the changes in the nominal exchange rate is significantly rejected, except for the quantiles $\tau=\{0.40$ to 0.60$\}$ or $\tau=\{0.95\}$. In addition, the relationship in which Korean international reserves cause changes in the nominal effective exchange rate is statistically significant except for the quantiles $\tau=\{0.45$ to 0.55$\}$. Conversely, with the exception of quantiles $\tau=\{0.45$ to 0.50$\}$, the changes in exchange rates Granger cause the changes in Korean international reserves at the $1 \%$ significance level. This means that compared to other countries, Korea has a stronger quantile-dependent causal relationship and bi-directional causality between the two variables.

On the other hand, in order to understand the motivations of each country's monetary authorities to intervene in the market, it is necessary to analyze the causal relationship between the exchange rate and the reserves as well as the regression coefficient between the two variables. In Tables 4 and 5, we present the estimated coefficients $\beta(\tau)$ of the quantile autoregressive (QAR) regression model of the relationship between the changes in international reserves and the changes in foreign exchange rates of 
each country. The shaded parts in Tables 4 and 5 denote the results of the estimated coefficients together with the significant causal relationship between the two variables in Appendix B Tables A2-A6.

In the case of China and Hong Kong, the quantile regression coefficients between the changes in the nominal exchange rate and the changes in foreign exchange reserves are not statistically significant in all quantiles of the distribution. This means that on the partial quantiles in Appendix B Tables A2 and A5, in China and Hong Kong, there is a causal relationship between the nominal exchange rate changes and the foreign reserves change, but the coefficient does not indicate a significant level. In Taiwan, the quantile regression coefficients in the causal relationship of the changes from the Taiwan international reserves to the changes in the nominal exchange rate in Appendix B Table A4 are significant at the quantiles $\tau=\{0.35,0.65\}$. This indicates that the positive changes in Taiwan international reserves cause negative changes in the nominal exchange rates of the New Taiwan Dollar per U.S. dollar, denoting the depreciation of the currency of Taiwan. In addition, in Korea, regarding the relation of the changes from international reserves to the changes in nominal exchange rate, the estimated coefficients indicating a significant causal relationship are negative in the ranges of quantiles $\tau=\{0.05$ to 0.35$\}$ or $\tau=\{0.65$ to 0.85$\}$. The estimated coefficient values are higher in both tails of the significant quantiles than in the middle bounds; the estimated coefficients $\beta(\tau)$ are -0.487 and -0.308 at the quantiles $\tau=\{0.05,0.85\}$, respectively. This indicates the quantiles-dependence and the strong tail-dependence of the distribution. Only in Korea, the significant coefficients in the causal relationship of the changes from the nominal exchange rate to the changes in international reserves are found at the quantiles $\tau=\{0.60,0.80\}$, but the intensities are smaller than the opposite causality. In short, Table 4 shows that except for some quantiles in Taiwan and Korea, the quantile regression coefficients evidencing a causal relationship between the changes in international reserves and the changes in nominal exchange rate are not statistically significant. Thus, in this case, it is difficult to find evidence of intentional intervention by the monetary authorities in each country.

However, in Table 5, the quantile regression coefficients indicative of a significant causal relationship between the changes in foreign reserves and the changes in the nominal effective exchange rate shows different evidence. In China, the estimated coefficients indicative of the significant causal relationship of the changes from the nominal effective exchange rate to the changes in international reserves are significantly negative in the quantiles $\tau=\{0.20,0.25,0.65,0.70,0.85\}$. In addition, in Hong Kong, the negative regression coefficients indicating the significant causal relationship between the changes from the nominal effective exchange rate and changes to the international reserves, are found in the ranges of quantiles $\tau=\{0.10$ to 0.40$\}$ or $\tau=\{0.55$ to 0.65$\}$. This indicates that the negative changes in the nominal effective exchange rate (in U.S. dollars) causes the positive changes in the international reserves in China and Hong Kong. In other words, the depreciation of currencies can cause an increase in foreign exchange reserves in China and Hong Kong. This can be interpreted that the monetary authorities have the mercantilist motive for making a response against the pressure of appreciation and the additional foreign capital inflows.

Conversely, in Japan, the estimated coefficients showing a significant causal relationship between the changes from the nominal effective exchange rate and the changes to international reserves are significantly positive in the ranges of quantiles $\tau=\{0.20$ to 0.35$\}$ or $\tau=\{0.50,0.55\}$. In Taiwan, although the regression coefficients are not significant, they are generally positive. In addition, in Korea, the positive regression coefficients indicative of a significant causal relationship between changes from the nominal effective exchange rate and the changes to international reserves are found in the ranges of quantiles $\tau=\{0.05$ to 0.40$\}$ or $\tau=\{0.55$ to 0.80$\}$. These results can be interpreted as the monetary authorities intervening in order to stabilize the value of their currencies. As these countries have discovered in the past, the depreciation of their currency, particularly a depreciation caused by negative economic shocks, has led to the continued declines in international reserves. The results of Japan and Korea can be seen as evidence of this type of response by their monetary authorities. 
Table 4. Estimated coefficients of the quantile regression between \% change of RES and FX rate.

\begin{tabular}{|c|c|c|c|c|c|c|c|c|c|c|}
\hline \multirow{2}{*}{$\begin{array}{c}\text { Quantile } \\
(\tau)\end{array}$} & \multicolumn{2}{|c|}{ China } & \multicolumn{2}{|c|}{ Japan } & \multicolumn{2}{|c|}{ Taiwan } & \multicolumn{2}{|c|}{ Hong Kong } & \multicolumn{2}{|c|}{ Korea } \\
\hline & RES $\nRightarrow F X$ Rate & FX Rate $\nRightarrow$ Res & RES $\nRightarrow F X$ Rate & FX Rate $\nRightarrow$ Res & RES $\nRightarrow F X$ Rate & FX Rate $\nRightarrow$ Res & RES $\nRightarrow F X$ Rate & FX Rate $\nRightarrow$ Res & RES $\nRightarrow F X$ Rate & FX Rate $\nRightarrow$ Res \\
\hline 0.05 & 0.097 & -0.151 & -0.158 & 0.028 & -0.201 & -0.127 & 0.007 & 2.263 & -0.487 & -0.210 \\
\hline 0.10 & 0.041 & 0.069 & -0.361 & 0.006 & -0.032 & -0.009 & 0.005 & -0.789 & -0.286 & -0.169 \\
\hline 0.15 & 0.039 & 0.027 & -0.244 & -0.025 & -0.089 & 0.029 & 0.004 & -0.791 & -0.273 & -0.061 \\
\hline 0.20 & 0.058 & -0.015 & -0.254 & -0.044 & -0.134 & -0.016 & 0.004 & -0.609 & -0.266 & -0.030 \\
\hline 0.25 & 0.045 & -0.013 & -0.314 & -0.021 & -0.150 & 0.008 & 0.002 & -0.167 & -0.239 & -0.027 \\
\hline 0.30 & 0.028 & 0.015 & -0.147 & -0.023 & -0.176 & 0.019 & 0.002 & 0.310 & -0.262 & -0.030 \\
\hline 0.35 & 0.020 & -0.002 & -0.240 & -0.021 & -0.191 & 0.020 & 0.002 & 0.520 & -0.247 & -0.042 \\
\hline 0.40 & 0.006 & -0.045 & -0.100 & -0.017 & -0.205 & 0.030 & 0.002 & 0.511 & -0.223 & -0.022 \\
\hline 0.45 & 0.003 & -0.091 & -0.101 & -0.004 & -0.198 & 0.046 & 0.001 & 0.455 & -0.231 & 0.018 \\
\hline 0.50 & 0.001 & -0.041 & -0.047 & -0.012 & -0.213 & 0.045 & 0.000 & 1.069 & -0.234 & 0.035 \\
\hline 0.55 & 0.000 & 0.017 & -0.134 & -0.023 & -0.175 & 0.084 & 0.001 & 0.735 & -0.183 & 0.052 \\
\hline 0.60 & 0.000 & -0.024 & -0.097 & -0.006 & -0.150 & 0.070 & 0.000 & 0.544 & -0.188 & 0.088 \\
\hline 0.65 & -0.002 & -0.001 & -0.091 & -0.014 & -0.164 & 0.099 & 0.000 & 0.721 & -0.225 & 0.082 \\
\hline 0.70 & -0.005 & 0.037 & -0.083 & -0.003 & -0.179 & 0.105 & 0.001 & 0.185 & -0.206 & 0.080 \\
\hline 0.75 & -0.016 & 0.137 & -0.053 & -0.036 & -0.213 & 0.089 & 0.001 & -0.351 & -0.229 & 0.114 \\
\hline 0.80 & -0.044 & -0.066 & -0.003 & -0.029 & -0.246 & 0.112 & 0.001 & 0.184 & -0.267 & 0.168 \\
\hline 0.85 & -0.074 & -0.272 & 0.026 & -0.075 & -0.186 & 0.115 & 0.001 & -0.853 & -0.308 & 0.174 \\
\hline 0.90 & -0.112 & -0.058 & -0.011 & -0.114 & -0.290 & 0.217 & 0.002 & -4.750 & -0.245 & 0.216 \\
\hline 0.95 & -0.178 & 0.212 & -0.022 & -0.143 & -0.371 & 0.387 & 0.004 & -1.652 & -0.417 & 0.523 \\
\hline
\end{tabular}

Notes: See the notes of Appendix A Table A1. This table presents the estimated coefficients $\beta(\tau)$ of the quantile autoregressive model in Equation (9). The bold text indicates the rejection of the null hypothesis at least the $5 \%$ significance level. The shaded parts denote the results of the estimated coefficients together with the significant causal relationship in Tables $2-5$ and A6 at lag 3. 
Table 5. Estimated coefficients of the quantile regression between \% change of RES and NEER.

\begin{tabular}{|c|c|c|c|c|c|c|c|c|c|c|}
\hline \multirow{2}{*}{$\begin{array}{l}\text { Quantile } \\
\qquad \boldsymbol{\tau})\end{array}$} & \multicolumn{2}{|c|}{ China } & \multicolumn{2}{|c|}{ Japan } & \multicolumn{2}{|c|}{ Taiwan } & \multicolumn{2}{|c|}{ Hong Kong } & \multicolumn{2}{|c|}{ Korea } \\
\hline & RES $\nRightarrow$ NEER & NEER $\nRightarrow$ Res & RES $\nRightarrow$ NEER & NEER $\nRightarrow$ Res & RES $\nRightarrow$ NEER & NEER $\nRightarrow$ Res & RES $\nRightarrow$ NEER & NEER $\nRightarrow$ Res & RES $\nRightarrow$ NEER & NEER $\nRightarrow$ Res \\
\hline 0.05 & -0.025 & -0.479 & 0.190 & 0.008 & 0.102 & 0.228 & 0.078 & -0.505 & 0.288 & 0.593 \\
\hline 0.10 & 0.016 & -0.466 & 0.185 & 0.034 & 0.038 & 0.227 & 0.063 & -0.550 & 0.071 & 0.445 \\
\hline 0.15 & -0.007 & -0.443 & 0.114 & 0.070 & 0.048 & 0.161 & 0.053 & -0.530 & 0.152 & 0.324 \\
\hline 0.20 & 0.027 & -0.346 & 0.092 & 0.089 & 0.007 & 0.126 & 0.042 & -0.389 & 0.167 & 0.297 \\
\hline 0.25 & 0.034 & -0.263 & 0.039 & 0.105 & -0.007 & 0.056 & 0.033 & -0.259 & 0.157 & 0.273 \\
\hline 0.30 & 0.024 & -0.196 & 0.066 & 0.085 & -0.049 & 0.056 & 0.030 & -0.291 & 0.133 & 0.260 \\
\hline 0.35 & 0.029 & -0.216 & 0.076 & 0.093 & -0.035 & 0.070 & 0.027 & -0.313 & 0.179 & 0.254 \\
\hline 0.40 & 0.038 & -0.241 & 0.046 & 0.086 & -0.043 & 0.040 & 0.021 & -0.330 & 0.158 & 0.249 \\
\hline 0.45 & 0.070 & -0.262 & 0.004 & 0.084 & -0.056 & 0.053 & 0.005 & -0.397 & 0.171 & 0.260 \\
\hline 0.50 & 0.086 & -0.288 & 0.070 & 0.104 & -0.030 & 0.030 & -0.002 & -0.375 & 0.204 & 0.261 \\
\hline 0.55 & 0.051 & -0.256 & 0.051 & 0.093 & -0.038 & 0.064 & -0.005 & -0.380 & 0.176 & 0.262 \\
\hline 0.60 & 0.069 & -0.299 & 0.033 & 0.068 & -0.055 & 0.045 & -0.012 & -0.361 & 0.185 & 0.222 \\
\hline 0.65 & 0.074 & -0.307 & 0.032 & 0.090 & -0.071 & 0.023 & -0.011 & -0.324 & 0.171 & 0.245 \\
\hline 0.70 & 0.063 & -0.352 & 0.046 & 0.082 & -0.101 & 0.032 & -0.009 & -0.270 & 0.210 & 0.236 \\
\hline 0.75 & 0.088 & -0.325 & -0.016 & 0.080 & -0.062 & 0.033 & -0.006 & -0.240 & 0.204 & 0.224 \\
\hline 0.80 & 0.111 & -0.354 & -0.038 & 0.088 & 0.008 & 0.080 & -0.002 & -0.206 & 0.184 & 0.202 \\
\hline 0.85 & 0.075 & -0.360 & 0.018 & 0.120 & 0.017 & 0.015 & 0.005 & -0.205 & 0.187 & 0.164 \\
\hline 0.90 & 0.047 & -0.409 & 0.226 & 0.192 & -0.04 & -0.122 & 0.010 & -0.049 & 0.237 & 0.181 \\
\hline 0.95 & -0.002 & -0.400 & 0.117 & 0.423 & -0.124 & -0.177 & 0.020 & -0.081 & 0.269 & 0.160 \\
\hline
\end{tabular}

Notes: See the notes of Appendix A Table A1. This table presents the estimated coefficients $\beta(\tau)$ of the quantile autoregressive model in Equation (9). The bold text indicates the rejection of the null hypothesis at least the $5 \%$ significance level. The shaded parts denote the results of the estimated coefficients together with the significant causal relationship in Tables $2-5$ and A6 at lag 3 . 
Meanwhile, except for Korea, four countries do not have significant coefficients reflecting a causal relationship of the changes from international reserves to the changes in the nominal effective exchange rate. This is interpreted that each country's sterilized policy is working well, except that of Korea. In the case of Korea, the positive coefficients indicative of a significant causal relationship between changes from international reserves to changes in the nominal effective exchange rate are found in the quantiles in the ranges of quantiles $\tau=\{0.20,0.25\}, \tau=\{0.35,0.40\}$, or $\tau=\{0.60$ to 0.90$\}$.

\section{Conclusions}

This study analyzed the relationship between the changes in international reserves and the exchange rate movements for major Far Eastern countries (China, Japan, Taiwan, Hong Kong, and Korea) from January 1997 to May 2020. This study used the quantile Granger causality (Granger causality in quantile) test and the quantile autoregressive model QAR(3) to capture the monetary authorities' intervention motivations according to the quantiles of distribution. The main results of this study are as follows.

First, the motivation for changing international reserves varies from country to country. In China and Hong Kong, the causal relationship and the estimated coefficients show that in these countries, there was a mercantilist motive of accumulating international reserves for the purpose of being able to respond to the appreciation of currencies, and it would have helped to maintain the export competitiveness of China and Hong Kong. The results of Korea and Japan show that the monetary authorities' motivation is relatively high for precautionary stabilizing their currencies. This would have helped Korea and Japan defend against external negative economic shocks. Although the estimation results were not significant, Taiwan was similar to Japan and Korea.

Second, we identified the asymmetric causal relationship between the changes in international reserves and the changes in exchange rates. In most quantiles of each country, the changes in international reserves did not significantly cause the changes in exchange rates. Considering the causal relationship with significant regression coefficients, these characteristics were more evident in all countries. It means that each monetary authorities' sterilized policy is working well. Only, in some quantiles of Korea, the bi-directional causality with significant regression coefficients was observed.

Last, we confirmed the existence of a quantile- and tail-dependent relationship between the variables. In all countries, the causal relationship between the changes in international reserves and the exchange rate movements was more clearly observed on both sides of the edge than in the middle level. In particular, Korea had a relatively stronger tail-dependence than other countries. That is, the causal relationship between the Korean foreign exchange reserves and the exchange rate is stronger at the rapid fluctuations of the variables, and this relationship is weakened at the moderate fluctuations of them.

Author Contributions: All the authors contributed to the entire process of writing this paper. Y.L. and S.-M.Y. conceived the idea and designed the structure of this paper. Y.L. collected and examined the data and devised the methodology. Y.L. wrote the draft of Sections 3 and 4, S.-M.Y. wrote Sections 1, 2 and 5, and S.-M.Y. performed a final revision of the entire paper. All authors have read and agreed to the published version of the manuscript.

Funding: This work was supported by the Ministry of Education of the Republic of Korea and the National Research Foundation of Korea (NRF-2017S1A5B8057488).

Conflicts of Interest: The authors declare no conflict of interest. 


\section{Appendix A}

Table A1. Descriptive statistics for the \% changes in the series.

\begin{tabular}{|c|c|c|c|c|c|c|c|c|c|c|c|c|c|c|c|}
\hline & \multicolumn{3}{|c|}{ China } & \multicolumn{3}{|c|}{ Japan } & \multicolumn{3}{|c|}{ Taiwan } & \multicolumn{3}{|c|}{ Hong Kong } & \multicolumn{3}{|c|}{ Korea } \\
\hline & FX Rate & NEER & RES & FX Rate & NEER & RES & FX Rate & NEER & RES & FX Rate & NEER & RES & $\begin{array}{c}\text { FX } \\
\text { Rate }\end{array}$ & NEER & RES \\
\hline Mean & -0.059 & 0.124 & 1.192 & -0.032 & 0.104 & 0.660 & 0.032 & -0.002 & 0.608 & 0.001 & 0.028 & 0.682 & 0.129 & -0.087 & 0.921 \\
\hline Median & -0.006 & 0.190 & 0.978 & 0.049 & -0.049 & 0.295 & -0.012 & 0.066 & 0.427 & 0.003 & -0.025 & 0.456 & -0.076 & 0.170 & 0.556 \\
\hline Std. dev. & 0.629 & 1.182 & 1.693 & 2.441 & 2.344 & 1.877 & 1.298 & 0.980 & 1.198 & 0.111 & 1.064 & 3.553 & 3.418 & 3.100 & 3.112 \\
\hline Minimum & -2.611 & -3.537 & -4.106 & -10.52 & -6.695 & -8.313 & -4.501 & -5.705 & -3.358 & -0.555 & -3.434 & -44.47 & -8.927 & -35.26 & -22.33 \\
\hline Maximum & 3.813 & 4.964 & 6.046 & 7.379 & 10.559 & 10.278 & 6.826 & 2.914 & 5.848 & 0.385 & 4.741 & 18.825 & 36.878 & 9.207 & 17.798 \\
\hline Skewness & 1.260 & 0.138 & 0.062 & -0.334 & 0.503 & 2.085 & 0.539 & -0.744 & 0.626 & -0.633 & 0.340 & -6.852 & 4.946 & -5.545 & -1.323 \\
\hline Kurtosis & 11.045 & 4.247 & 3.122 & 4.156 & 4.848 & 12.912 & 6.469 & 6.593 & 6.245 & 7.828 & 4.667 & 97.462 & 51.934 & 62.803 & 23.465 \\
\hline$J-B \chi^{2}$ & 826.13 & 18.957 & 0.354 & 20.746 & 51.436 & 1344.3 & 153.41 & 175.81 & 154.55 & 289.60 & 37.67 & 105914 & 28974 & 43005 & 4950.4 \\
\hline Probability & 0.000 & 0.000 & 0.838 & 0.000 & 0.000 & 0.000 & 0.000 & 0.000 & 0.000 & 0.000 & 0.000 & 0.000 & 0.000 & 0.000 & 0.000 \\
\hline Correlation & -0.270 & -0.118 & - & -0.277 & 0.092 & - & -0.461 & 0.183 & _- & -0.034 & -0.079 & _- & -0.572 & 0.560 & - \\
\hline
\end{tabular}

Notes: The FX rate denotes the \% changes in the nominal exchange rates. The NEER denotes the \% changes in the nominal effective exchange rates (in U.S. dollars). The RES denotes the \% changes in the foreign exchange reserves. $J-B \chi^{2}$ is the Jarque-Bera statistic. The probability is the $p$-value. The correlation is denoted by the coefficient between the RES and FX rate and that between the RES and the NEER.

\section{Appendix B}

Table A2. Quantile Granger causality test between the \% change of reserves and FX rate (and NEER) in case of China.

\begin{tabular}{|c|c|c|c|c|c|c|c|c|c|c|c|c|}
\hline \multirow{2}{*}{$\begin{array}{c}\text { China } \\
\begin{array}{c}\text { Quantile } \\
(\tau)\end{array}\end{array}$} & \multicolumn{3}{|c|}{ RES $\nRightarrow$ FX Rate } & \multicolumn{3}{|c|}{ RES $\nLeftarrow$ FX Rate } & \multicolumn{3}{|c|}{ RES $\nRightarrow$ NEER } & \multicolumn{3}{|c|}{$\mathbf{R E S} \nLeftarrow \mathbf{N E E R}$} \\
\hline & Lags $=1$ & Lags $=2$ & Lags $=3$ & Lags $=1$ & Lags $=2$ & Lags $=3$ & Lags $=1$ & Lags $=2$ & Lags $=3$ & Lags $=1$ & Lags $=2$ & Lags $=3$ \\
\hline all & 0.004 & 0.004 & 0.004 & 0.009 & 0.009 & 0.004 & 0.222 & 0.487 & 0.330 & 0.009 & 0.009 & 0.004 \\
\hline 0.05 & 0.574 & 0.487 & 0.530 & 0.843 & 0.800 & 0.570 & 0.191 & 0.209 & 0.048 & 0.843 & 0.800 & 0.570 \\
\hline 0.10 & 0.157 & 0.009 & 0.013 & 0.448 & 0.409 & 0.661 & 0.357 & 0.752 & 0.809 & 0.448 & 0.409 & 0.661 \\
\hline 0.15 & 0.004 & 0.004 & 0.004 & 0.122 & 0.174 & 0.152 & 0.174 & 0.187 & 0.174 & 0.122 & 0.174 & 0.152 \\
\hline 0.20 & 0.004 & 0.004 & 0.004 & 0.022 & 0.026 & 0.004 & 0.278 & 0.017 & 0.409 & 0.022 & 0.026 & 0.004 \\
\hline 0.25 & 0.017 & 0.022 & 0.022 & 0.004 & 0.004 & 0.004 & 0.139 & 0.061 & 0.004 & 0.004 & 0.004 & 0.004 \\
\hline 0.30 & 0.017 & 0.017 & 0.022 & 0.004 & 0.004 & 0.004 & 0.065 & 0.022 & 0.004 & 0.004 & 0.004 & 0.004 \\
\hline 0.35 & 0.017 & 0.065 & 0.017 & 0.004 & 0.057 & 0.013 & 0.030 & 0.143 & 0.283 & 0.004 & 0.057 & 0.013 \\
\hline 0.40 & 0.091 & 0.083 & 0.083 & 0.004 & 0.117 & 0.822 & 0.452 & 1.000 & 0.691 & 0.004 & 0.117 & 0.822 \\
\hline
\end{tabular}


Table A2. Cont.

\begin{tabular}{|c|c|c|c|c|c|c|c|c|c|c|c|c|}
\hline \multirow{2}{*}{$\begin{array}{c}\text { China } \\
\begin{array}{c}\text { Quantile } \\
(\tau)\end{array}\end{array}$} & \multicolumn{3}{|c|}{ RES $\nRightarrow$ FX Rate } & \multicolumn{3}{|c|}{ RES $\nLeftarrow$ FX Rate } & \multicolumn{3}{|c|}{ RES $\nRightarrow$ NEER } & \multicolumn{3}{|c|}{ RES $\nLeftarrow$ NEER } \\
\hline & Lags $=1$ & Lags $=2$ & Lags $=3$ & Lags $=1$ & Lags $=2$ & Lags $=3$ & Lags $=1$ & Lags $=2$ & Lags $=3$ & Lags $=1$ & Lags $=2$ & Lags $=3$ \\
\hline 0.45 & 0.087 & 0.070 & 0.083 & 0.452 & 0.796 & 1.000 & 0.704 & 0.913 & 0.783 & 0.452 & 0.796 & 1.000 \\
\hline 0.50 & 0.113 & 0.109 & 0.100 & 0.361 & 0.857 & 0.304 & 0.643 & 0.648 & 0.865 & 0.361 & 0.857 & 0.304 \\
\hline 0.55 & 0.004 & 0.004 & 0.004 & 0.243 & 0.313 & 0.109 & 0.691 & 0.691 & 0.674 & 0.243 & 0.313 & 0.109 \\
\hline 0.60 & 0.004 & 0.004 & 0.004 & 0.257 & 0.174 & 0.143 & 0.204 & 0.857 & 1.000 & 0.257 & 0.174 & 0.143 \\
\hline 0.65 & 0.004 & 0.004 & 0.004 & 0.109 & 0.074 & 0.004 & 1.000 & 0.809 & 1.000 & 0.109 & 0.074 & 0.004 \\
\hline 0.70 & 0.004 & 0.004 & 0.004 & 0.030 & 0.004 & 0.004 & 0.548 & 0.530 & 1.000 & 0.030 & 0.004 & 0.004 \\
\hline 0.75 & 0.004 & 0.004 & 0.004 & 0.017 & 0.026 & 0.043 & 0.761 & 0.791 & 0.757 & 0.017 & 0.026 & 0.043 \\
\hline 0.80 & 0.004 & 0.004 & 0.004 & 0.374 & 0.274 & 0.183 & 0.083 & 0.013 & 0.430 & 0.374 & 0.274 & 0.183 \\
\hline 0.85 & 0.004 & 0.004 & 0.004 & 0.039 & 0.070 & 0.004 & 0.461 & 1.000 & 1.000 & 0.039 & 0.070 & 0.004 \\
\hline 0.90 & 0.191 & 0.191 & 0.191 & 0.113 & 0.713 & 0.639 & 0.165 & 0.474 & 0.696 & 0.113 & 0.713 & 0.639 \\
\hline 0.95 & 1.000 & 0.709 & 0.730 & 1.000 & 1.000 & 0.283 & 0.004 & 0.265 & 0.004 & 1.000 & 1.000 & 0.283 \\
\hline
\end{tabular}

Notes: See the notes of Appendix A Table A1. The null hypothesis is Granger non-causality. This table shows the $p$-values of the quantile Granger non-causality test. The bold text indicates the rejection of the null hypothesis at the $1 \%$ significance level.

Table A3. Quantile Granger causality test between the \% change of reserves and FX rate (and NEER) in case of Japan.

\begin{tabular}{|c|c|c|c|c|c|c|c|c|c|c|c|c|}
\hline \multirow{2}{*}{$\begin{array}{c}\text { Japan } \\
\text { Quantile } \\
(\tau)\end{array}$} & \multicolumn{3}{|c|}{$\mathbf{R E S} \nRightarrow \mathbf{F X}$ rate } & \multicolumn{3}{|c|}{$\mathbf{R E S} \nLeftarrow F \mathbf{F X}$ rate } & \multicolumn{3}{|c|}{ RES $\nRightarrow$ NEER } & \multicolumn{3}{|c|}{$\mathbf{R E S} \nLeftarrow \mathbf{N E E R}$} \\
\hline & Lags $=1$ & Lags $=2$ & Lags $=3$ & Lags $=1$ & Lags $=2$ & Lags $=3$ & Lags $=1$ & Lags $=2$ & Lags $=3$ & Lags $=1$ & Lags $=2$ & Lags $=3$ \\
\hline all & 0.230 & 0.387 & 0.430 & 0.004 & 0.004 & 0.004 & 0.209 & 0.161 & 0.083 & 0.004 & 0.004 & 0.004 \\
\hline 0.05 & 1.000 & 0.817 & 1.000 & 0.004 & 0.004 & 0.004 & 0.252 & 0.117 & 0.113 & 0.004 & 0.004 & 0.004 \\
\hline 0.10 & 0.313 & 0.235 & 0.257 & 0.004 & 0.004 & 0.004 & 0.243 & 0.296 & 0.139 & 0.004 & 0.004 & 0.004 \\
\hline 0.15 & 0.091 & 0.743 & 0.735 & 0.004 & 0.004 & 0.004 & 0.100 & 0.026 & 0.017 & 0.004 & 0.004 & 0.004 \\
\hline 0.20 & 1.000 & 0.639 & 0.570 & 0.004 & 0.004 & 0.004 & 1.000 & 1.000 & 0.548 & 0.004 & 0.004 & 0.004 \\
\hline 0.25 & 0.152 & 0.778 & 0.526 & 0.004 & 0.004 & 0.004 & 0.822 & 0.804 & 0.748 & 0.004 & 0.004 & 0.004 \\
\hline 0.30 & 0.252 & 0.296 & 0.687 & 0.004 & 0.004 & 0.004 & 0.191 & 0.057 & 0.126 & 0.004 & 0.004 & 0.004 \\
\hline 0.35 & 0.791 & 0.817 & 0.783 & 0.004 & 0.004 & 0.004 & 0.565 & 0.774 & 1.000 & 0.004 & 0.004 & 0.004 \\
\hline 0.40 & 0.239 & 0.161 & 0.483 & 1.000 & 0.983 & 0.865 & 0.491 & 0.304 & 0.026 & 0.926 & 0.943 & 0.865 \\
\hline 0.45 & 0.174 & 0.335 & 0.613 & 0.113 & 0.309 & 0.452 & 0.704 & 0.291 & 0.339 & 0.113 & 0.309 & 0.452 \\
\hline 0.50 & 0.226 & 0.187 & 0.135 & 0.004 & 0.004 & 0.004 & 0.322 & 0.296 & 0.187 & 0.004 & 0.004 & 0.004 \\
\hline 0.55 & 0.100 & 0.252 & 0.165 & 0.004 & 0.004 & 0.004 & 0.117 & 0.061 & 0.100 & 0.004 & 0.004 & 0.004 \\
\hline 0.60 & 0.239 & 0.348 & 0.013 & 0.004 & 0.004 & 0.004 & 0.296 & 0.317 & 0.122 & 0.004 & 0.004 & 0.004 \\
\hline
\end{tabular}


Table A3. Cont.

\begin{tabular}{|c|c|c|c|c|c|c|c|c|c|c|c|c|}
\hline \multirow{2}{*}{$\begin{array}{c}\text { Japan } \\
\text { Quantile } \\
(\tau)\end{array}$} & \multicolumn{3}{|c|}{$\mathrm{RES} \nRightarrow \mathrm{FX}$ rate } & \multicolumn{3}{|c|}{$\mathbf{R E S} \nLeftarrow \mathbf{F X}$ rate } & \multicolumn{3}{|c|}{ RES $\nRightarrow N E E R$} & \multicolumn{3}{|c|}{$\mathbf{R E S} \nLeftarrow \mathbf{N E E R}$} \\
\hline & Lags $=1$ & Lags $=2$ & Lags $=3$ & Lags $=1$ & Lags $=2$ & Lags $=3$ & Lags $=1$ & Lags $=2$ & Lags $=3$ & Lags $=1$ & Lags $=2$ & Lags $=3$ \\
\hline 0.65 & 0.291 & 0.630 & 0.135 & 0.004 & 0.004 & 0.004 & 0.030 & 0.026 & 0.039 & 0.004 & 0.004 & 0.004 \\
\hline 0.70 & 0.496 & 0.304 & 0.570 & 0.004 & 0.004 & 0.004 & 0.104 & 0.213 & 0.309 & 0.004 & 0.004 & 0.004 \\
\hline 0.75 & 0.465 & 0.161 & 0.065 & 0.004 & 0.004 & 0.004 & 0.265 & 0.257 & 0.304 & 0.004 & 0.004 & 0.004 \\
\hline 0.80 & 0.483 & 0.483 & 0.417 & 0.004 & 0.004 & 0.004 & 0.396 & 0.496 & 0.130 & 0.004 & 0.004 & 0.004 \\
\hline 0.85 & 0.274 & 0.248 & 1.000 & 0.004 & 0.004 & 0.004 & 0.035 & 0.052 & 0.039 & 0.004 & 0.004 & 0.004 \\
\hline 0.90 & 0.065 & 0.065 & 0.252 & 0.004 & 0.004 & 0.004 & 0.700 & 0.687 & 0.357 & 0.004 & 0.004 & 0.004 \\
\hline 0.95 & 0.122 & 0.091 & 0.157 & 1.000 & 0.457 & 0.322 & 1.000 & 1.000 & 1.000 & 1.000 & 0.457 & 0.322 \\
\hline
\end{tabular}

Notes: See the notes of Appendix A Table A1. The null hypothesis is Granger non-causality. This table shows the $p$-values of the quantile Granger non-causality test. The bold text indicates the rejection of the null hypothesis at the $1 \%$ significance level.

Table A4. Quantile Granger causality test between the \% change of reserves and FX rate (and NEER) in case of Taiwan.

\begin{tabular}{|c|c|c|c|c|c|c|c|c|c|c|c|c|}
\hline \multirow{2}{*}{$\begin{array}{c}\text { Taiwan } \\
\text { Quantile } \\
(\tau)\end{array}$} & \multicolumn{3}{|c|}{$\mathrm{RES} \nRightarrow \mathrm{FX}$ rate } & \multicolumn{3}{|c|}{$\mathrm{RES} \nLeftarrow \mathrm{FX}$ rate } & \multicolumn{3}{|c|}{ RES $\nRightarrow$ NEER } & \multicolumn{3}{|c|}{ RES $\nLeftarrow$ NEER } \\
\hline & Lags $=1$ & Lags $=2$ & Lags $=3$ & Lags $=1$ & Lags $=2$ & Lags $=3$ & Lags $=1$ & Lags $=2$ & Lags $=3$ & Lags $=1$ & Lags $=2$ & Lags $=3$ \\
\hline all & 0.004 & 0.004 & 0.004 & 0.004 & 0.004 & 0.004 & 0.061 & 0.017 & 0.035 & 0.004 & 0.004 & 0.004 \\
\hline 0.05 & 1.000 & 1.000 & 1.000 & 0.378 & 0.322 & 0.335 & 1.000 & 1.000 & 1.000 & 0.378 & 0.322 & 0.335 \\
\hline 0.10 & 0.004 & 0.004 & 0.004 & 0.039 & 0.039 & 0.022 & 0.004 & 0.004 & 0.013 & 0.039 & 0.039 & 0.022 \\
\hline 0.15 & 0.022 & 0.022 & 0.009 & 0.004 & 0.004 & 0.004 & 0.387 & 0.322 & 0.122 & 0.004 & 0.004 & 0.004 \\
\hline 0.20 & 0.013 & 0.013 & 0.017 & 0.004 & 0.004 & 0.004 & 0.026 & 0.013 & 0.004 & 0.004 & 0.004 & 0.004 \\
\hline 0.25 & 0.009 & 0.013 & 0.009 & 0.004 & 0.004 & 0.004 & 0.043 & 0.052 & 0.030 & 0.004 & 0.004 & 0.004 \\
\hline 0.30 & 0.061 & 0.022 & 0.026 & 0.004 & 0.004 & 0.004 & 0.013 & 0.070 & 0.017 & 0.004 & 0.004 & 0.004 \\
\hline 0.35 & 0.004 & 0.004 & 0.004 & 0.217 & 0.057 & 0.083 & 0.191 & 0.287 & 0.326 & 0.217 & 0.057 & 0.083 \\
\hline 0.40 & 0.004 & 0.022 & 0.013 & 0.826 & 0.700 & 1.000 & 0.174 & 0.270 & 0.239 & 0.826 & 0.700 & 1.000 \\
\hline 0.45 & 0.635 & 1.000 & 1.000 & 0.483 & 0.457 & 0.278 & 0.313 & 0.348 & 0.165 & 0.483 & 0.457 & 0.278 \\
\hline 0.50 & 0.317 & 0.317 & 0.339 & 0.052 & 0.004 & 0.004 & 0.370 & 0.278 & 0.300 & 0.052 & 0.004 & 0.004 \\
\hline 0.55 & 0.117 & 0.174 & 0.161 & 0.004 & 0.004 & 0.004 & 0.635 & 0.661 & 0.465 & 0.004 & 0.004 & 0.004 \\
\hline 0.60 & 0.004 & 0.017 & 0.009 & 0.004 & 0.004 & 0.004 & 0.391 & 0.452 & 0.426 & 0.004 & 0.004 & 0.004 \\
\hline 0.65 & 0.004 & 0.004 & 0.004 & 0.004 & 0.004 & 0.004 & 0.774 & 0.657 & 0.378 & 0.004 & 0.004 & 0.004 \\
\hline 0.70 & 0.004 & 0.004 & 0.004 & 0.004 & 0.004 & 0.004 & 1.000 & 1.000 & 1.000 & 0.004 & 0.004 & 0.004 \\
\hline 0.75 & 0.004 & 0.004 & 0.004 & 0.004 & 0.004 & 0.004 & 0.474 & 0.852 & 0.448 & 0.004 & 0.004 & 0.004 \\
\hline
\end{tabular}


Table A4. Cont.

\begin{tabular}{|c|c|c|c|c|c|c|c|c|c|c|c|c|}
\hline \multirow{2}{*}{$\begin{array}{c}\text { Taiwan } \\
\text { Quantile } \\
(\tau)\end{array}$} & \multicolumn{3}{|c|}{$\mathrm{RES} \nRightarrow \mathrm{FX}$ rate } & \multicolumn{3}{|c|}{$\mathrm{RES} \nLeftarrow \mathrm{FX}$ rate } & \multicolumn{3}{|c|}{ RES $\nRightarrow$ NEER } & \multicolumn{3}{|c|}{$\mathbf{R E S} \nLeftarrow \mathbf{N E E R}$} \\
\hline & Lags $=1$ & Lags $=2$ & Lags $=3$ & Lags $=1$ & Lags = 2 & Lags $=3$ & Lags $=1$ & Lags $=2$ & Lags $=3$ & Lags $=1$ & Lags $=2$ & Lags $=3$ \\
\hline 0.80 & 0.004 & 0.004 & 0.004 & 0.104 & 0.165 & 0.378 & 0.004 & 0.048 & 0.052 & 0.104 & 0.165 & 0.378 \\
\hline 0.85 & 0.004 & 0.052 & 0.017 & 1.000 & 0.361 & 0.174 & 0.004 & 0.004 & 0.057 & 1.000 & 0.361 & 0.174 \\
\hline 0.90 & 0.035 & 0.017 & 0.004 & 0.426 & 0.774 & 1.000 & 0.004 & 0.004 & 0.004 & 0.426 & 0.774 & 1.000 \\
\hline 0.95 & 1.000 & 1.000 & 1.000 & 0.087 & 0.070 & 0.074 & 0.074 & 0.022 & 0.022 & 0.087 & 0.070 & 0.074 \\
\hline
\end{tabular}

Table A5. Quantile Granger causality test between the \% change of reserves and FX rate (and NEER) in case of Hong Kong.

\begin{tabular}{|c|c|c|c|c|c|c|c|c|c|c|c|c|}
\hline \multirow{2}{*}{$\begin{array}{c}\text { Hong Kong } \\
\text { Quantile } \\
(\tau)\end{array}$} & \multicolumn{3}{|c|}{$\mathrm{RES} \nRightarrow \mathrm{FX}$ rate } & \multicolumn{3}{|c|}{$\mathbf{R E S} \nLeftarrow \mathbf{F X}$ rate } & \multicolumn{3}{|c|}{ RES $\nRightarrow$ NEER } & \multicolumn{3}{|c|}{ RES $\nLeftarrow$ NEER } \\
\hline & Lags $=1$ & Lags $=2$ & Lags $=3$ & Lags $=1$ & Lags $=2$ & Lags $=3$ & Lags $=1$ & Lags $=2$ & Lags $=3$ & Lags $=1$ & Lags $=2$ & Lags $=3$ \\
\hline all & 0.004 & 0.039 & 0.022 & 0.004 & 0.004 & 0.004 & 0.183 & 0.309 & 0.313 & 0.004 & 0.004 & 0.004 \\
\hline 0.05 & 1.000 & 1.000 & 1.000 & 0.004 & 0.004 & 0.004 & 0.709 & 0.600 & 0.657 & 0.004 & 0.004 & 0.004 \\
\hline 0.10 & 0.096 & 0.248 & 0.213 & 0.004 & 0.004 & 0.004 & 0.448 & 0.496 & 0.726 & 0.004 & 0.004 & 0.004 \\
\hline 0.15 & 0.004 & 0.004 & 0.004 & 0.004 & 0.004 & 0.004 & 0.074 & 0.052 & 0.030 & 0.004 & 0.004 & 0.004 \\
\hline 0.20 & 0.004 & 0.004 & 0.004 & 0.004 & 0.004 & 0.004 & 0.039 & 0.057 & 0.043 & 0.004 & 0.004 & 0.004 \\
\hline 0.25 & 0.004 & 0.004 & 0.004 & 0.004 & 0.004 & 0.004 & 0.004 & 0.004 & 0.004 & 0.004 & 0.004 & 0.004 \\
\hline 0.30 & 0.004 & 0.057 & 0.043 & 0.004 & 0.004 & 0.004 & 0.283 & 0.157 & 0.187 & 0.004 & 0.004 & 0.004 \\
\hline 0.35 & 0.004 & 0.061 & 0.061 & 0.004 & 0.004 & 0.004 & 0.500 & 0.822 & 0.865 & 0.004 & 0.004 & 0.004 \\
\hline 0.40 & 0.057 & 0.057 & 0.048 & 0.004 & 0.004 & 0.004 & 0.626 & 0.609 & 0.413 & 0.004 & 0.004 & 0.004 \\
\hline 0.45 & 0.096 & 0.091 & 0.087 & 0.126 & 0.170 & 0.152 & 0.396 & 0.743 & 0.730 & 0.126 & 0.170 & 0.152 \\
\hline 0.50 & 0.265 & 0.457 & 0.439 & 0.130 & 0.113 & 0.204 & 0.778 & 0.383 & 0.378 & 0.130 & 0.113 & 0.204 \\
\hline 0.55 & 0.126 & 0.222 & 0.178 & 0.004 & 0.004 & 0.004 & 0.213 & 0.304 & 0.443 & 0.004 & 0.004 & 0.004 \\
\hline 0.60 & 0.026 & 0.070 & 0.065 & 0.004 & 0.004 & 0.004 & 0.087 & 0.235 & 0.335 & 0.004 & 0.004 & 0.004 \\
\hline 0.65 & 0.004 & 0.017 & 0.004 & 0.004 & 0.004 & 0.004 & 0.391 & 0.552 & 0.548 & 0.004 & 0.004 & 0.004 \\
\hline 0.70 & 0.004 & 0.004 & 0.004 & 0.004 & 0.004 & 0.004 & 0.739 & 1.000 & 1.000 & 0.004 & 0.004 & 0.004 \\
\hline 0.75 & 0.004 & 0.004 & 0.004 & 0.004 & 0.004 & 0.004 & 0.743 & 0.217 & 0.161 & 0.004 & 0.004 & 0.004 \\
\hline 0.80 & 0.004 & 0.004 & 0.004 & 0.004 & 0.004 & 0.004 & 0.070 & 0.078 & 0.230 & 0.004 & 0.004 & 0.004 \\
\hline 0.85 & 0.004 & 0.004 & 0.004 & 0.004 & 0.004 & 0.004 & 0.474 & 0.783 & 0.670 & 0.004 & 0.004 & 0.004 \\
\hline 0.90 & 0.004 & 0.004 & 0.004 & 0.004 & 0.004 & 0.004 & 0.096 & 0.065 & 0.078 & 0.004 & 0.004 & 0.004 \\
\hline 0.95 & 1.000 & 1.000 & 1.000 & 0.009 & 0.157 & 0.004 & 0.083 & 0.474 & 0.483 & 0.009 & 0.157 & 0.004 \\
\hline
\end{tabular}

Notes: See the notes of Appendix A Table A1. The null hypothesis is Granger non-causality. This table shows the $p$-values of the quantile Granger non-causality test. The bold text indicates the rejection of the null hypothesis at the $1 \%$ significance level. 
Table A6. Quantile Granger causality test between the \% change of reserves and FX rate (and NEER) in case of Korea.

\begin{tabular}{|c|c|c|c|c|c|c|c|c|c|c|c|c|}
\hline \multirow{2}{*}{$\begin{array}{c}\text { Korea } \\
\text { Quantile } \\
(\tau)\end{array}$} & \multicolumn{3}{|c|}{$\mathrm{RES} \nRightarrow \mathrm{FX}$ rate } & \multicolumn{3}{|c|}{ RES $\nLeftarrow$ FX rate } & \multicolumn{3}{|c|}{ RES $\nRightarrow$ NEER } & \multicolumn{3}{|c|}{ RES $\nLeftarrow$ NEER } \\
\hline & Lags $=1$ & Lags $=2$ & Lags $=3$ & Lags $=1$ & Lags $=2$ & Lags $=3$ & Lags $=1$ & Lags $=2$ & Lags $=3$ & Lags $=1$ & Lags $=2$ & Lags $=3$ \\
\hline all & 0.004 & 0.004 & 0.004 & 0.004 & 0.004 & 0.004 & 0.004 & 0.004 & 0.004 & 0.004 & 0.004 & 0.004 \\
\hline 0.05 & 0.004 & 0.004 & 0.004 & 0.004 & 0.004 & 0.004 & 0.004 & 0.004 & 0.004 & 0.004 & 0.004 & 0.004 \\
\hline 0.10 & 0.004 & 0.004 & 0.004 & 0.004 & 0.004 & 0.004 & 0.004 & 0.004 & 0.004 & 0.004 & 0.004 & 0.004 \\
\hline 0.15 & 0.004 & 0.004 & 0.004 & 0.004 & 0.004 & 0.004 & 0.004 & 0.004 & 0.004 & 0.004 & 0.004 & 0.004 \\
\hline 0.20 & 0.004 & 0.004 & 0.004 & 0.004 & 0.004 & 0.004 & 0.004 & 0.004 & 0.004 & 0.004 & 0.004 & 0.004 \\
\hline 0.25 & 0.004 & 0.004 & 0.004 & 0.004 & 0.004 & 0.004 & 0.004 & 0.004 & 0.004 & 0.004 & 0.004 & 0.004 \\
\hline 0.30 & 0.004 & 0.004 & 0.004 & 0.004 & 0.004 & 0.004 & 0.004 & 0.004 & 0.004 & 0.004 & 0.004 & 0.004 \\
\hline 0.35 & 0.004 & 0.004 & 0.004 & 0.004 & 0.004 & 0.004 & 0.004 & 0.004 & 0.004 & 0.004 & 0.004 & 0.004 \\
\hline 0.40 & 0.104 & 0.439 & 0.122 & 0.004 & 0.004 & 0.004 & 0.004 & 0.004 & 0.004 & 0.004 & 0.004 & 0.004 \\
\hline 0.45 & 0.143 & 0.870 & 0.904 & 0.043 & 0.283 & 0.252 & 0.004 & 0.087 & 0.183 & 0.043 & 0.283 & 0.252 \\
\hline 0.50 & 0.265 & 0.070 & 0.400 & 0.048 & 0.004 & 0.087 & 0.265 & 0.174 & 0.222 & 0.048 & 0.004 & 0.087 \\
\hline 0.55 & 0.074 & 0.039 & 0.035 & 0.004 & 0.004 & 0.004 & 0.904 & 0.674 & 0.617 & 0.004 & 0.004 & 0.004 \\
\hline 0.60 & 0.004 & 0.026 & 0.035 & 0.004 & 0.004 & 0.004 & 0.004 & 0.004 & 0.009 & 0.004 & 0.004 & 0.004 \\
\hline 0.65 & 0.004 & 0.004 & 0.004 & 0.004 & 0.004 & 0.004 & 0.004 & 0.004 & 0.004 & 0.004 & 0.004 & 0.004 \\
\hline 0.70 & 0.004 & 0.004 & 0.004 & 0.004 & 0.004 & 0.004 & 0.004 & 0.004 & 0.004 & 0.004 & 0.004 & 0.004 \\
\hline 0.75 & 0.004 & 0.004 & 0.004 & 0.004 & 0.004 & 0.004 & 0.004 & 0.004 & 0.004 & 0.004 & 0.004 & 0.004 \\
\hline 0.80 & 0.004 & 0.004 & 0.004 & 0.004 & 0.004 & 0.004 & 0.004 & 0.004 & 0.004 & 0.004 & 0.004 & 0.004 \\
\hline 0.85 & 0.004 & 0.004 & 0.004 & 0.004 & 0.004 & 0.004 & 0.004 & 0.004 & 0.004 & 0.004 & 0.004 & 0.004 \\
\hline 0.90 & 0.004 & 0.004 & 0.004 & 0.004 & 0.004 & 0.004 & 0.004 & 0.004 & 0.004 & 0.004 & 0.004 & 0.004 \\
\hline 0.95 & 0.004 & 0.013 & 0.004 & 0.004 & 0.004 & 0.009 & 0.004 & 0.004 & 0.004 & 0.004 & 0.004 & 0.009 \\
\hline
\end{tabular}

Notes: See the notes of Appendix A Table A1. The null hypothesis is Granger non-causality. This table shows the $p$-values of the quantile Granger non-causality test. The bold text indicates the rejection of the null hypothesis at the $1 \%$ significance level. 


\section{References}

1. Cavusoglu, N. Exchange rates and the effectiveness of actual and oral official interventions: A survey on findings, issues and policy implications. Glob. Econ. J. 2010, 10, 3. [CrossRef]

2. Sarno, L.; Taylor, M.P. Official intervention in the foreign exchange market: Is it effective and, if so, how does it work? J. Econ. Lett. 2001, 39, 839-868. [CrossRef]

3. Ehlers, T.; Takáts, E. Capital Flow Dynamics and FX Intervention: Market Volatility and Foreign Exchange Intervention in EMEs: What Has Changed? BIS Papers 73. 2013, pp. 25-38. Available online: https://www.bis.org/ publ/bppdf/bispap73c_rh.pdf (accessed on 31 March 2020).

4. Mohanty, M.S. Market Volatility and Foreign Exchange Intervention in EMEs: What Has Changed: An Overview. BIS Papers 73. 2013, pp. 1-10. Available online: https://www.bis.org/publ/bppdf/bispap73a_ rh.pdf (accessed on 31 March 2020).

5. Pontines, V.; Rajan, R.S. Foreign exchange market intervention and reserve accumulation in emerging Asia: Is there evidence of fear of appreciation? Econ. Lett. 2011, 111, 252-255. [CrossRef]

6. Disyatat, P.; Galati, G. The effectiveness of foreign exchange intervention in emerging market countries: Evidence from the Czech koruna. J. Int. Money Finance 2007, 26, 383-402. [CrossRef]

7. Fry-McKibbin, R.A.; Wanaguru, S. Currency intervention: A case study of an emerging market. J. Int. Money Finance 2013, 37, 25-47. [CrossRef]

8. Calvo, G.A.; Reinhart, C.M. Fear of floating. Q. J. Econ. 2002, 117, 379-408. [CrossRef]

9. Bahmani-Oskoee, M.; Brown, F. Demand for international reserves: A review article. Appl. Econ. 2002, 34, 1209-1226. [CrossRef]

10. IMF Data. Data Template on International Reserves and Foreign Currency Liquidity (IRFCL). Available online: https://data.imf.org/?sk=2DFB3380-3603-4D2C-90BE-A04D8BBCE237/ (accessed on 31 March 2020).

11. Cheng, T.; Liu, X. Foreign exchange reserves: A new challenge to China. J. Post Keynes. Econ. 2013, 35, 621-650. [CrossRef]

12. Bernanke, B.S. Financial Reform to Address Systemic Risk; Speech at the Council on Foreign Relations, Board of Governors of the Federal Reserve System: Washington, DC, USA, 2009.

13. Dunaway, S. Global Imbalances and the Financial Crisis: Council Special Report No. 44, March 2009; Council on Foreign Relations (Council on Foreign Relations Press): New York, NJ, USA, 2009.

14. Granger, C.W.J. Investigating causal relations by econometric models and crossspectral methods. Econometrica 1969, 37, 424-438. [CrossRef]

15. Krugman, P. Revenge of the glut. The New York Times, 1 March 2009.

16. Obstfeld, M.; Rogoff, K. Global Imbalances and the Financial Crisis: Products of Common Causes. CEPR Discussion Paper No. 7606. 2009. Available online: https://eml.berkeley.edu/ \{\}obstfeld/santabarbara. pdf (accessed on 31 March 2020).

17. Portes, R. Global imbalances. In Macroeconomic Stability and Financial Regulation: Key Issues for the G20; Dewatripont, M., Freixas, X., Portes, R., Eds.; Centre for Economic Policy Research: London, UK, 2009; pp. 19-26.

18. Borio, C.; Disyatat, P. Global Imbalances and the Financial Crisis: Link or No Link? BIS Working Papers 346. 2011. Available online: https://www.bis.org/publ/work346.pdf (accessed on 31 March 2020).

19. Canales-Kriljenko, J.I. Foreign Exchange Intervention in Developing and Transition Economies: Results of a Survey. IMF Working Paper 03/95. 2003. Available online: https://www.imf.org/en/Publications/WP/ Issues/2016/12/30/Foreign-Exchange-Intervention-in-Developing-and-Transition-Economies-Results-of-aSurvey-16514 (accessed on 31 March 2020).

20. Schnabl, G. Exchange rate volatility and growth in small open economies at the EMU periphery. Econ. Syst. 2008, 32, 70-91. [CrossRef]

21. Caporale, G.M.; Ali, F.M.; Spagnolo, F.; Spagnolo, N. International portfolio flows and exchange rate volatility in emerging Asian markets. J. Int. Money Finance 2017, 76, 1-15. [CrossRef]

22. Hausmann, R.; Panizza, U.; Stein, E. Why do countries float the way they float? J. Dev. Econ. 2001, 66, 387-414. [CrossRef]

23. Sula, O. Demand for international reserves in developing nations: A quantile regression approach. J. Int. Money Finance 2011, 30, 764-777. [CrossRef] 
24. Dutta, J.; Leon, H. Dread of Depreciation: Measuring Real Exchange Rate Interventions. IMF Working Paper 02/63. 2002. Available online: https://www.imf.org/en/Publications/WP/Issues/2016/12/30/Dread-ofDepreciation-Measuring-Real-Exchange-Rate-Interventions-15739 (accessed on 31 March 2020).

25. Levy-Yeyati, E.; Sturzenegger, F.; Gluzmann, P.A. Fear of appreciation. J. Dev. Econ. 2013, 101, 233-247. [CrossRef]

26. Filardo, A.; Yetman, J. The Expansion of Central Bank Balance Sheets in Emerging Asia: What Are the Risks? BIS Quarterly Review. June 2012. Available online: https://www.bis.org/publ/qtrpdf/r_qt1206g.pdf (accessed on 31 March 2020).

27. Levy-Yeyati, E.; Gomez, J.-F. The Cost of Holding Foreign Exchange Reserves. CID Working Papers 353. 2019. Available online: http://www.tinyurl.com/y49k266q (accessed on 31 March 2020).

28. Park, D.; Estrada, G.E.B. Are Developing Asia's Foreign Exchange Reserves Excessive? An Empirical Examination. 2009. Available online: https://www.adb.org/sites/default/files/publication/28389/economicswp170.pdf (accessed on 31 March 2020).

29. Rodrik, D. The social cost of foreign exchange reserves. Int. Econ. J. 2006, 20, 253-266. [CrossRef]

30. Rodrik, D. The real exchange rate and economic growth. Brook. Pap. Econ. Act. 2008, 39, 365-412. [CrossRef]

31. Trairatvorakul, P. Policy Panel: Regional Challenges Ahead-Dealing with Capital Flows, Prolonged Exchange Rate Intervention and Their Consequences in Asia and the Pacific. In Are Central Bank Balance Sheets in Asia too Large? BIS Papers 66; Bank for International Settlements: Basel, Switzerland, 2012; Available online: http://www.bis.org/publ/bppdf/bispap66x.pdf (accessed on 31 March 2020).

32. Gallagher, K.P.; Shrestha, E. The social cost of self-insurance: Financial crisis, reserve accumulation, and developing countries. Glob. Polit. 2012, 3, 501-509. [CrossRef]

33. Aizenman, J.; Marion, N. The high demand for international reserves in the Far East: What's going on? J. Jpn. Int. Econ. 2003, 17, 370-400. [CrossRef]

34. Aizenman, J.; Lee, J. International reserves: Precautionary versus mercantilist views, theory and evidence. Open Econ. Rev. 2007, 18, 191-214. [CrossRef]

35. Aizenman, J.; Lee, J. Financial versus monetary mercantilism: Long-run view of large international reserves hoarding. World Econ. 2008, 31, 593-611. [CrossRef]

36. Aizenman, J.; Lee, J. Real exchange rate, mercantilism and the learning by doing externality. Pac. Econ. Rev. 2010, 15, 324-335. [CrossRef]

37. Delatte, A.-L.; Fouquau, J. What drove the massive hoarding of international reserves in emerging economies? A time-varying approach. Rev. Int. Econ. 2012, 20, 164-176. [CrossRef]

38. Dooley, M.P.; Folkerts-Landau, D.; Garber, P. The revived Bretton Woods system. Int. J. Finance Econ. 2004, 9, 307-313. [CrossRef]

39. Srinivasan, N.; Kumar, S. Zone-quadratic preference, asymmetry and international reserve accretion in India: An empirical investigation. J. Int. Financ. Mark. Inst. Money 2012, 22, 253-263. [CrossRef]

40. Srinivasan, N.; Mahambare, V.; Ramachandran, M. Preference asymmetry and international reserve accretion in India. Appl. Econ. Lett. 2009, 16, 1543-1546. [CrossRef]

41. Perron, P. The great crash, the oil price shock, and the unit root hypothesis. Econometrica 1989, 57, 1361-1401. [CrossRef]

42. Ben-Bassat, A.; Gottlieb, D. Optimal international reserves and sovereign risk. J. Int. Econ. 1992, 33, 345-362. [CrossRef]

43. Cheung, Y.-W.; Qian, X.; Remolona, E. Hoarding of international reserves: It's a neighbourly day in Asia. Pac. Econ. Rev. 2019, 24, 208-240. [CrossRef]

44. Durdu, C.B.; Mendoza, E.G.; Terrones, M.E. Precautionary demand for foreign assets in sudden stop economies: An assessment of the new mercantilism. J. Dev. Econ. 2009, 89, 194-209. [CrossRef]

45. García, P.; Soto, C. Large Hoardings of International Reserves: Are They Worth It? Working Papers Central Bank of Chile 299; Central Bank of Chile: Santiago, Chile, 2004.

46. Jeanne, O.; Rancière, R. The optimal level of international reserves for emerging market countries: A new formula and some applications. Econ. J. 2011, 121, 905-930. [CrossRef]

47. Kim, Y.J. Sudden stops, limited enforcement, and optimal reserves. Int. Rev. Econ. Finance 2017, 51, 273-282. [CrossRef]

48. Korinek, A.; Servén, L. Undervaluation through foreign reserve accumulation: Static losses, dynamic gains. J. Int. Money Financ. 2016, 64, 104-136. [CrossRef] 
49. Lee, J. Insurance Value of International Reserves: An Option Pricing Approach. IMF Working Papers 04/175. 2004. Available online: http://dx.doi.org/10.5089/9781451858785.001 (accessed on 31 March 2020).

50. Obstfeld, M.; Shambaugh, J.C.; Taylor, A.M. Financial stability, the trilemma, and international reserves. Am. Econ. J. Macroecon. 2010, 2, 57-94. [CrossRef]

51. Caballero, R.J.; Farhi, E.; Gourinchas, P.-O. An equilibrium model of global Imbalances and low interest rates. Am. Econ. Rev. 2008, 98, 358-393. [CrossRef]

52. Filardo, A.J.; Siklos, P.L. Prolonged reserves accumulation, credit booms, asset prices and monetary policy in Asia. Emerg. Mark. Finance Trade 2016, 52, 364-381. [CrossRef]

53. Lane, P.R.; Burke, D. The empirics of foreign reserves. Open Econ. Rev. 2001, 12, 423-434. [CrossRef]

54. Troster, V. Testing for Granger-causality in quantiles. Econom. Rev. 2016, 1, 1-17. [CrossRef]

55. Wikipedia. List of Countries by Foreign-Exchange Reserves. Available online: https://en.wikipedia.org/ wiki/List_of_countries_by_foreign\$-\$exchange_reserves/ (accessed on 31 March 2020).

56. FRED Economic Data. Exchange Rates. Available online: https:/fred.stlouisfed.org/categories/15/ (accessed on 31 March 2020).

57. IMF Data. Currency Composition of Official Foreign Exchange Reserves (COFER). Available online: https://data.imf.org/?sk=E6A5F467-C14B-4AA8-9F6D-5A09EC4E62A4/ (accessed on 31 March 2020).

58. BIS Statistics. Effective Exchange Rate Indices. Available online: https://www.bis.org/statistics/eer.htm/ (accessed on 31 March 2020).

59. Perron, P.; Vogelsang, T.J. Nonstationarity and level shifts with an application to purchasing power parity. J. Bus. Econ. Stat. 1992, 10, 301-320.

60. Perron, P.; Vogelsang, T.J. Testing for a unit root in a time series with a changing mean: Corrections and extensions. J. Bus. Econ. Stat. 1992, 10, 467-470.

61. Phillips, P.C.B.; Perron, P. Testing for a unit root in time series regression. Biometrika 1988, 75, 335-346. [CrossRef]

62. Johansen, S. Estimation and hypothesis testing of cointegration vectors in Gaussian vector autoregressive models. Econometrica 1991, 59, 1551-1580. [CrossRef]

63. Johansen, S. Likelihood-Based Inference in Cointegrated Vector Autoregressive Models; Oxford University Press: Oxford, UK, 1995.

(C) 2020 by the authors. Licensee MDPI, Basel, Switzerland. This article is an open access article distributed under the terms and conditions of the Creative Commons Attribution (CC BY) license (http://creativecommons.org/licenses/by/4.0/). 